\title{
Serotonin and Antidepressant SSRIs Inhibit Rat Neuroendocrine Dopamine Neurons: Parallel Actions in the Lactotrophic Axis
}

\author{
○David J. Lyons, ${ }^{2}{ }^{\odot}$ Rachida Ammari, ${ }^{1}$ Arash Hellysaz, ${ }^{1}$ and ${ }^{\oplus}$ Christian Broberger ${ }^{1}$ \\ ${ }^{1}$ Department of Neuroscience, Karolinska Institutet, 17177 Stockholm, Sweden, and ${ }^{2}$ Rowett Institute of Nutrition and Health, University of Aberdeen, \\ Institute of Medical Sciences, Foresterhill, Aberdeen AB25 2ZD, United Kingdom
}

Selective serotonin reuptake inhibitors (SSRIs) are commonly prescribed for depression, but sexual side effects often compromise compliance. These reproductive dysfunctions are likely mediated by elevations of the hormone prolactin. Yet, how serotonin (5-HT) and SSRIs cause changes in prolactin secretion is not known. Here, using in vitro whole-cell patch-clamp recordings, we show that 5-HT hyperpolarizes and abolishes phasic discharge in rat neuroendocrine tuberoinfundibular dopamine (TIDA) neurons, the main inhibitor of prolactin secretion. This process is underpinned by $5-\mathrm{HT}_{1 \mathrm{~A}}$ receptor-mediated activation of G-protein-coupled inwardly rectifying $\mathrm{K}^{+}$-like currents. We further demonstrate that the SSRIs, fluoxetine and sertraline, directly suppress TIDA neuron activity through parallel effects, independent of 5-HT transmission. This inhibition involves decreased intrinsic excitability and a slowing of TIDA network rhythms. These findings indicate that SSRIs may inhibit neuroendocrine dopamine release through both 5-HT-dependent and -independent actions, providing a mechanistic explanation for, and potential molecular targets for the amelioration of, the hyperprolactinemia and sexual dysfunction associated with these drugs.

Key words: depression; dopamine; fluoxetine; neuroendocrine; prolactin; tuberoinfundibular

Significance Statement

Depression affects approximately one-tenth of the population and is commonly treated with selective serotonin reuptake inhibitors (SSRIs; e.g., Prozac). Yet, many patients withdraw from SSRI therapy due to sexual side effects (e.g., infertility, menstrual disturbances, and impotence). Although it is generally accepted that sexual side effects are due to the ability of these drugs to elevate blood levels of the hormone prolactin, the mechanism for this hormonal imbalance is not known. Here, we show that SSRIs can inhibit hypothalamic dopamine neurons that normally suppress the secretion of prolactin. Intriguingly this inhibition can be explained both by increased serotonin activity and also by parallel serotonin-independent actions.

\section{Introduction}

Selective serotonin reuptake inhibitors (SSRIs) were originally developed for the treatment of mood disorders but have also been approved to treat a widening spectrum of conditions, including

\footnotetext{
Received Nov. 11, 2015; revised May 20, 2016; accepted May 24, 2016.

Author contributions:D.J.L. and C.B. designed research;D.J.L., R.A., and A.H. performed research;D.J.L., R.A., and A.H. analyzed data; D.J.L. and C.B. wrote the paper.

This work was supported by European Research Council ENDOSWITCH 261286, Swedish Research Council 20143906, Strategic Research Programme in Diabetes at Karolinska Institutet, and Novo Nordisk Fonden to C.B. D.J.L. was supported by Wenner-Gren Foundations postdoctoral fellowship. The authors thank Dr. April Johnston for advice on serotonin pharmacology and Dr. Pradeep Atluri for discussions on clinical manifestations of SSRI treatment.

The authors declare no competing financial interests.

Correspondence should be addressed to either of the following: Dr. David J. Lyons, Rowett Institute of Nutrition and Health, University of Aberdeen, Institute of Medical Sciences, Foresterhill, Aberdeen AB25 2ZD, United Kingdom, E-mail: david.lyons@abdn.ac.uk; or Dr. Christian Broberger, Department of Neuroscience, Karolinska Institutet, Retzius v. 8, 17177 Stockholm, Sweden. E-mail: Christian.Broberger@ki.se.

DOI:10.1523/JNEUROSCI.4061-15.2016

Copyright $\odot 2016$ the authors $\quad 0270-6474 / 16 / 367392-15 \$ 15.00 / 0$
}

anxiety, obsessive compulsive disorder, and bulimia nervosa. Depressive disorders, with a global prevalence exceeding $4 \%$ (Vos et al., 2012), are projected to be the leading cause of disease burden by 2030 (World Health Organisation, 2008). SSRIs are recommended as a front-line therapy for moderate to severe depression (American Psychiatric Association, 2000), and population prevalence of SSRI use as high as 3.5\% has been described (Olié et al., 2002). Unfortunately, SSRI compliance is compromised by the high incidence of adverse effects. Sexual side effects, including amenorrhea, infertility, anorgasmia, impotence, and impaired libido, are often under-reported (Montejo-González et al., 1997) but, when systematically assessed, are experienced by $\sim 40 \%$ of all SSRI users (Clayton et al., 2002), often leading to cessation of treatment (van Geffen et al., 2007).

The adverse sexual effects associated with SSRIs are commonly attributed to elevation of the pituitary hormone, prolactin (Safarinejad, 2008; Madhusoodanan et al., 2010). Prolactin exerts 
a range of physiological effects that decrease fertility and libido (Bole-Feysot et al., 1998), and hyperprolactinemia, caused, for example, by pituitary adenomas or induced iatrogenically, results in reproductive dysfunction, such as menstrual disturbances and impotence (e.g., Schlechte et al., 1980; Buvat et al., 1985). Hyperprolactinemia is common with SSRIs, such as fluoxetine (Prozac) and sertraline (Urban and Veldhuis, 1991; Ekselius et al., 1997; Gregorian et al., 2002; Petit et al., 2003), and was originally described in animal studies (e.g., Morgan and Herbert, 1978). Importantly, serotonin (5-HT) itself was first shown to be a potent prolactin-releasing agent $>4$ decades ago (Kamberi et al., 1971; Lu and Meites, 1973).

It is not well understood how 5-HT and SSRIs promote prolactin release (Emiliano and Fudge, 2004). Direct stimulation of prolactin-producing lactotrophs is unlikely because administration of 5-HT to isolated pituitary preparations does not promote prolactin secretion (Birge et al., 1970). The release of prolactin is, however, under powerful control by neuroendocrine tuberoinfundibular dopamine (TIDA) neurons located in the hypothalamic arcuate nucleus (Lyons and Broberger, 2014). Dopamine released from TIDA neurons reaches the pituitary through the portal capillary system and tonically suppresses prolactin release via inhibitory dopamine D2-type receptors. Recent work suggests that neuromodulators and hormones that influence prolactin release and lactation may do this by altering the passive and active membrane properties of TIDA neurons (Lyons et al., 2010, 2012; Briffaud et al., 2015; Zhang and van den Pol, 2015) Here, we have investigated whether 5-HT and three SSRIs (fluoxetine, sertraline, and fenfluramine) can alter the electrophysiology of TIDA cells in a way that may explain the prolactin-releasing actions of these compounds.

\section{Materials and Methods \\ Animals}

Male Sprague Dawley rats (Charles River), 22- to 30-d-old for electrophysiology experiments and 4- to 6-weeks-old for immunofluorescence, were housed with free access to standard chow and tap water in a temperature-controlled environment under $12 \mathrm{~h} / 12 \mathrm{~h}$ light/dark conditions. All animal experiments had received prior approval by the local ethical board, Stockholms Norra Djurförsöksetiska Nämnd, and were performed in accordance with the European Communities Council Directive of November 24, 1986 (86/609/EEC).

\section{Electrophysiology}

Electrophysiological experiments were performed as previously described (Lyons et al., 2012). Rats ( $n=83$ ) were anesthetized with sodium pentobarbital and decapitated. The brain was removed and placed in cold, oxygenated $\left(95 \% \mathrm{O}_{2} / 5 \% \mathrm{CO}_{2}\right)$ "slicing" solution containing the following (in mM): 214 sucrose, $2.0 \mathrm{KCl}, 1.2 \mathrm{NaH}_{2} \mathrm{PO}_{4}, 26 \mathrm{NaHCO}_{3}, 1.3$ $\mathrm{MgSO}_{4}, 2.4 \mathrm{CaCl}_{2}$, and $10 \mathrm{D}$-glucose. The brain was glued to a vibratome (Leica), and $250 \mu \mathrm{m}$ thick coronal sections of the hypothalamus, including the arcuate nucleus, were prepared. Slices were immediately transferred to a "recording" solution containing the following (in mM): 127 $\mathrm{NaCl}, 2.0 \mathrm{KCl}, 1.2 \mathrm{NaH}_{2} \mathrm{PO}_{4}, 26 \mathrm{NaHCO}_{3}, 1.3 \mathrm{MgCl}_{2}, 2.4 \mathrm{CaCl}_{2}$, and 10 D-glucose, in a continuously oxygenated holding chamber at $35^{\circ} \mathrm{C}$ for a period of $25 \mathrm{~min}$. Subsequently, slices were allowed to recover in "recording" solution at room temperature for a minimum of $1 \mathrm{~h}$ before recording. For whole-cell recordings, slices were transferred to a submerged chamber and placed on an elevated grid that allows perfusion both above and below the slice. An Axioskop 2 FS Plus upright microscope (Carl Zeiss) was used for infrared-differential interference contrast visualization of cells. Recordings were performed at room temperature $\left(22^{\circ} \mathrm{C}\right)$, and slices were continuously perfused with oxygenated "recording" solution (as above) unless otherwise described at a rate of $\sim 5 \mathrm{ml} / \mathrm{min}$. All pharmacological compounds were bath applied.
Whole-cell current- and voltage-clamp recordings were performed with pipettes (3-7 $\mathrm{M} \Omega$ when filled with intracellular solution) made from borosilicate glass capillaries (World Precision Instruments) pulled on a P-97 Flaming/Brown micropipette puller (Sutter Instruments). The intracellular recording solution contained (in $\mathrm{mM}$ ) the following: 140 K-gluconate, $10 \mathrm{KCl}, 10 \mathrm{HEPES}, 1 \mathrm{EGTA}, 2 \mathrm{Na}_{2} \mathrm{ATP}$, pH 7.3 (with $\mathrm{KOH}$ ). When investigating IPSCs, a High $\mathrm{Cl}^{-}$intracellular solution was used comprised of the following (in mM): $150 \mathrm{KCl}, 10$ HEPES, 1 EGTA, 2 $\mathrm{Na}_{2} \mathrm{ATP}$ ), pH 7.3 (with $\mathrm{KOH}$ ). The concentration used for TTX was 500 $\mathrm{nM}$. In experiments that required the raising of $\mathrm{K}^{+}$conductances, reversal potential high $\mathrm{K}^{+}$extracellular recording solution containing the following (in mM): $127 \mathrm{NaCl}, 10 \mathrm{KCl}, 1.2 \mathrm{NaH}_{2} \mathrm{PO}_{4}, 26 \mathrm{NaHCO}_{3}, 1.3$ $\mathrm{MgCl}_{2}, 2.4 \mathrm{CaCl}_{2}, 10 \mathrm{D}$-glucose was used. Recordings were performed using a Multiclamp 700B amplifier and pClamp9 software (Molecular Devices). Access resistance was monitored throughout the experiments, and neurons in which the series resistance was $>25 \mathrm{~m} \Omega$ or changed $>15 \%$ were excluded from the statistics. Liquid junction potential was $16.4 \mathrm{mV}$ and not compensated. The recorded current was sampled at 10 $\mathrm{kHz}$ and filtered at $2 \mathrm{kHz}$ unless otherwise stated. In voltage-clamp experiments, the holding potential was $-60 \mathrm{mV}$ unless otherwise stated.

To determine the 5-HT-induced current in the presence of TTX frequency distribution, histograms were plotted for $10 \mathrm{~s}$ of control, 5-HT, and wash traces with Gaussian fits performed on the individual and pooled distributions. The mean difference between the Gaussian peaks for control and 5-HT was used as the value for 5-HT-induced current. The spectral density plot of the underlying oscillation was produced by filtering the trace with a $1 \mathrm{~Hz}$ low pass filter and performing spectral analysis with a rectangular window function on $56.5 \mathrm{~s}$ segments giving a spectral resolution of $0.019 \mathrm{~Hz}$. To quantify GABAergic synaptic events, $100 \mathrm{~s}$ segments in control and during response were selected for analysis and comparison.

\section{Immunofluorescence}

Rats $(n=4)$ were perfused with a fixative of $5 \%$ glutaraldehyde/ $1 \%$ sodium bisulfite in cacodylate buffer; $14-\mu \mathrm{m}$-thick coronal brain sections were processed for indirect immunofluorescence as previously described using mouse monoclonal anti-TH antibodies (1:2000; Millipore) and rabbit anti-serotonin (5-HT) antiserum (1:250; Millipore) (Foo et al., 2014).

\section{Statistical analysis and reagents}

Data analysis was performed with OriginPro8.5 (OriginLab), Clampfit 9 (Molecular Devices), and Mini Analysis 6.0.9 (Synaptosoft) software. Statistical significance was set at $p<0.05$. All reagents were purchased from Sigma Pharmaceuticals, with the exception of TTX, which was purchased from Alomone Labs, and 8-hydroxy PIPAT oxalate $( \pm)$-8-hydroxy-2-dipropylaminotetralin hydrobromide (8OH-DPAT), NAD299 hydrochloride, fluoxetine hydrochloride, sertraline hydrochloride, and dexfenfluramine hydrochloride, which were purchased from Tocris Bioscience.

\section{Results}

\section{5-HT directly inhibits oscillating TIDA neurons}

TIDA neurons display a synchronized network oscillation (Lyons et al., 2010, 2012), characterized by alternating periods of hyperpolarization and depolarization (Fig. 1A). This stereotyped oscillation provides a reliable electrical signature for rat TIDA neurons in vitro (Lyons et al., 2010, 2012). When 5-HT (10 $\mu \mathrm{M})$ was applied to TIDA neurons (in current-clamp mode), a reversible hyperpolarization and cessation of both oscillation and phasic discharge were consistently observed $(n=27$ of $27 ; 100 \%$; Fig. $1 A, B)$.

Immunohistochemical staining for $5-\mathrm{HT}$ and $\mathrm{TH}$ (the ratelimiting enzyme in catecholamine biosynthesis) revealed 5-HTimmunoreactive fibers in close apposition to TIDA somata and dendrites, thus providing an anatomical substrate for the direct 5-HT-ergic modulation of TIDA activity (Fig. 1C). This was confirmed pharmacologically, as in the presence of the $\mathrm{Na}^{+}$channel 
A

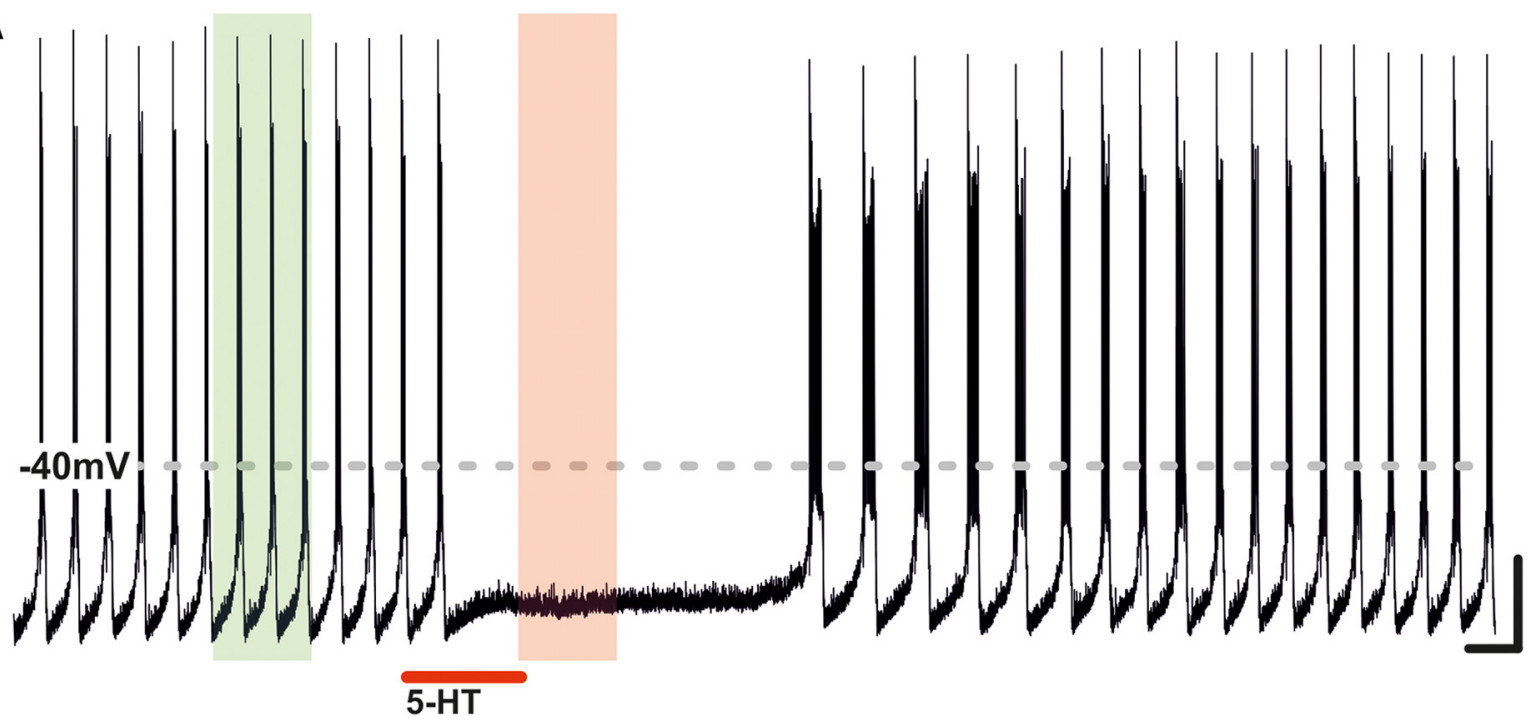

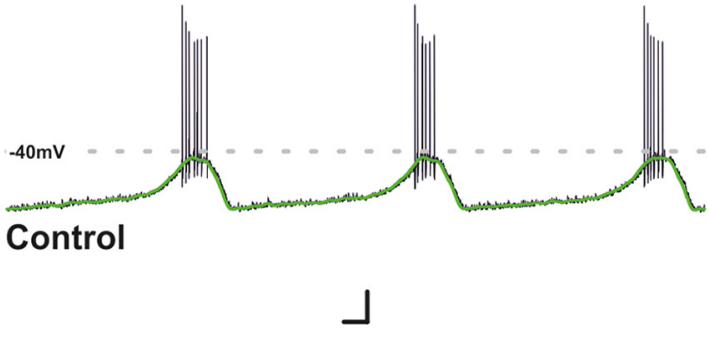

$-40 \mathrm{mV}$

5-HT

B

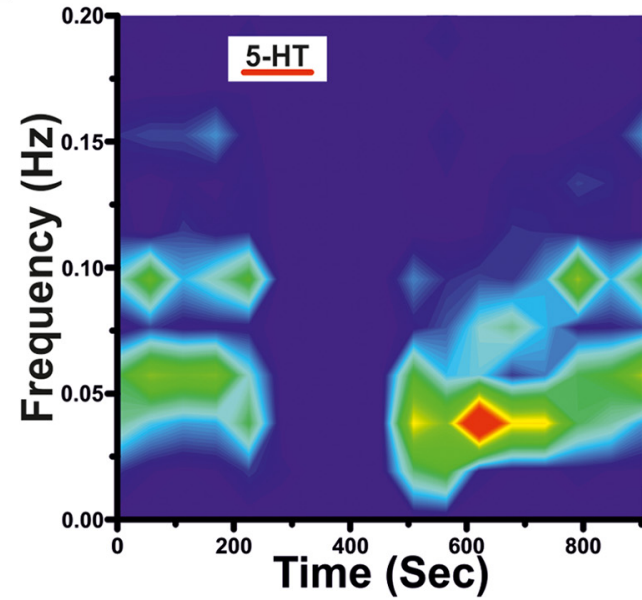

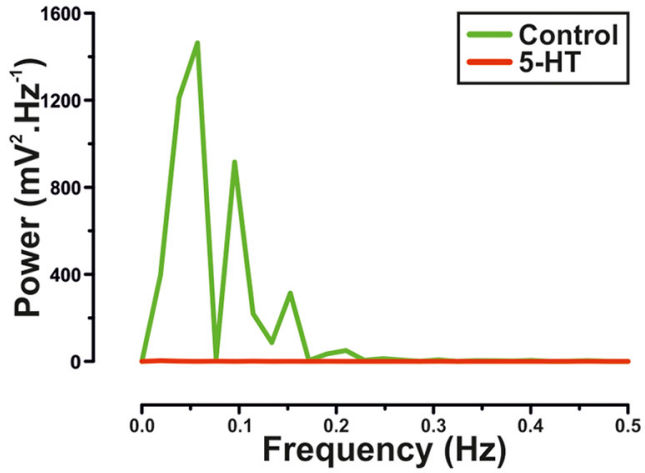

C

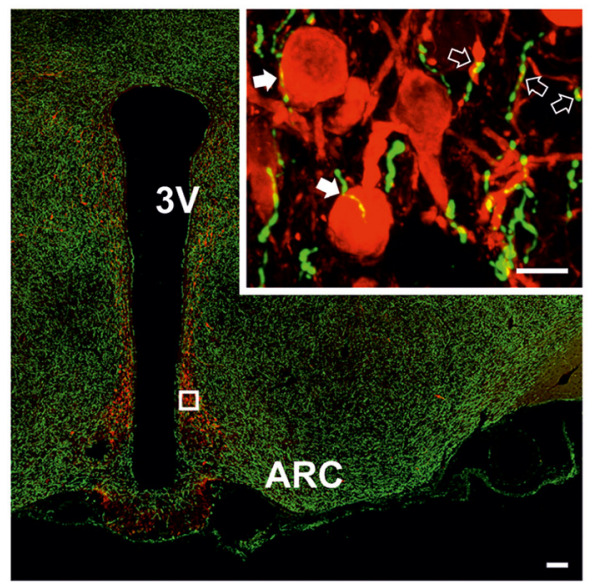

Figure 1. Serotonin inhibits TIDA neurons. A, Current-clamp, oscillating rat TIDA neuron. 5-HT (10 $\mu \mathrm{M})$ application results in hyperpolarization and abolishment of phasic discharge. Calibration: $20 \mathrm{mV}, 30 \mathrm{~s}$. Bottom, Expanded sections highlighted in $\boldsymbol{A}$ with the color-coordinated $1 \mathrm{~Hz}$ filter superimposed and the corresponding spectral analysis opposite. Calibration: $20 \mathrm{mV}, 2 \mathrm{~s}$. B, Frequency spectrogram of the entire trace depicted in $\boldsymbol{A}$. There is reversible abolishment of TIDA oscillation power by 5 -HT. $C$, Confocal micrographs from rat hypothalamus stained by immunofluorescence for TH (red) and 5-HT (green). Boxed area enlarged in Inset. 5-HT-immunoreactive terminals form close appositions on somata (filled arrows) and dendrites (open arrows) of TH-expressing TIDA neurons. Scale bars: $100 \mu \mathrm{m}$; Inset, $10 \mu \mathrm{m}$. 3V, Third ventricle; ARC, arcuate nucleus.

blocker TTX (500 nM), which also abolishes the TIDA oscillation (Lyons et al., 2010, 2012), 5-HT (10 $\mu \mathrm{M})$ induced a rapid and reversible $22.9 \pm 1.6 \mathrm{mV}$ hyperpolarization $(n=5 ; p<0.005$; ANOVA; $F_{(2,12)}=163.4$; Fig. $\left.2 A, B\right)$ (this value was used as a control 5-HT response for current-clamp tests where paired comparisons were not possible), and a $9.7 \pm 2.1 \%$ reduction in input resistance $\left(n=5 ; p<0.01\right.$; ANOVA; $F_{(2,12)}=10.7$; Fig. $2 A, B)$. A second application of $5-\mathrm{HT}$ resulted in a $19.3 \pm 2.0 \mathrm{mV}$ 


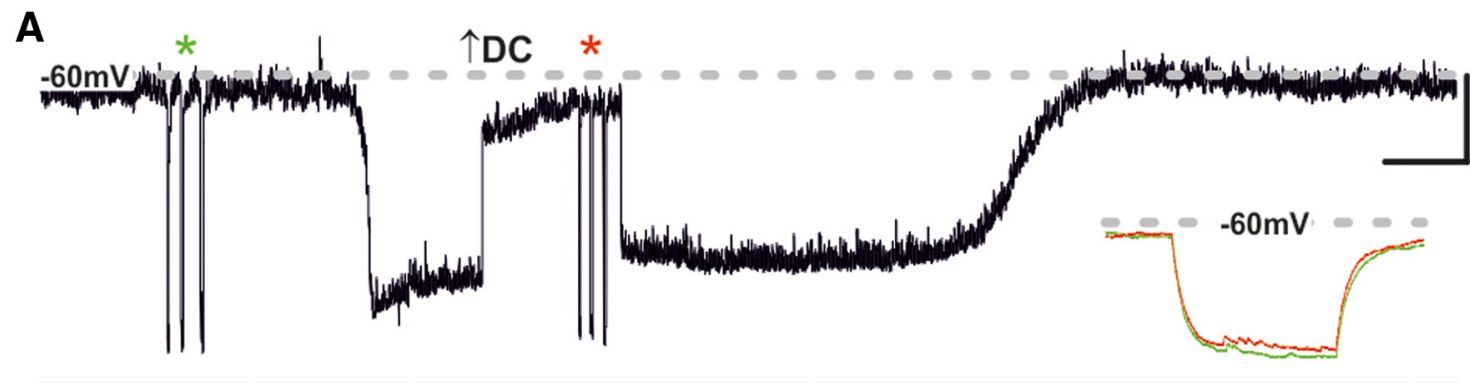

\section{TTX $\quad 5-\mathrm{HT}$}

B

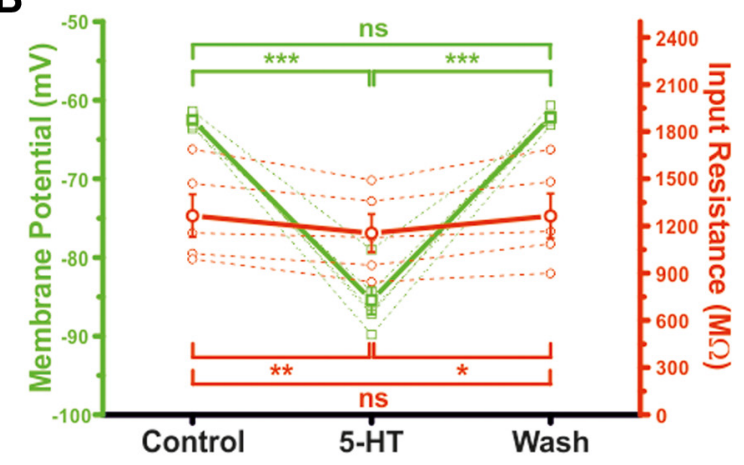

C

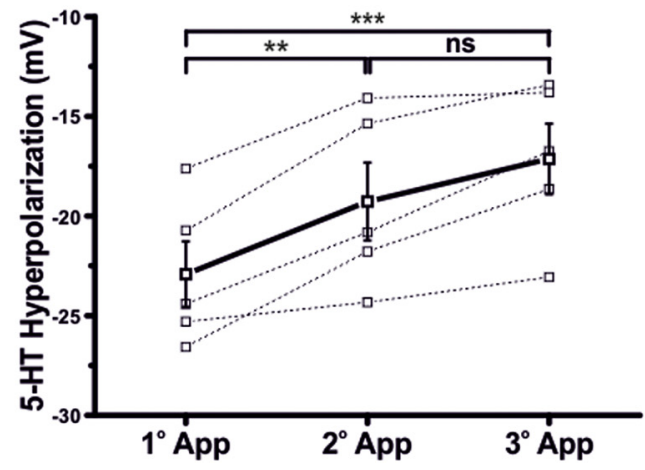

Figure 2. Serotonin inhibits TIDA neurons via a postsynaptic mechanism. $\boldsymbol{A}$, Current-clamp trace, oscillating TIDA neuron. The 5 -HT (10 $\mu \mathrm{m}$ )-induced hyperpolarization endures in the presence of TTX ( $500 \mathrm{~nm}$ ). Initial membrane potential was set at $\approx-65 \mathrm{mV}$, a value achieved with the injection of negative DC current. Input resistance was assessed by square-form negative current injection (asterisks). For purposes of comparison at peak of response, membrane potential was returned to $-65 \mathrm{mV}$ with additional DC current (arrow). Inset, Superimposed membrane potential deflections in control (green) and 5-HT (red). Calibration: $10 \mathrm{mV}, 20 \mathrm{~s}$; Inset, $20 \mathrm{mV}, 250 \mathrm{~ms}$. B, Summary of 5-HT-induced effects on membrane potential (green) and input resistance (red) recorded as in $\boldsymbol{A}$. Thick lines indicate mean \pm SEM. Dashed lines indicate raw data $(n=5)$. C, Desensitization of the 5-HT response recorded as in $\boldsymbol{A}$ following repeated applications (after 15 min of wash). Thick lines indicate mean \pm SEM. Dashed lines indicate raw data $(n=5) .{ }^{*} p<0.05$. ${ }^{* *} p<0.01 .{ }^{* * *} p<0.005$. ns, Not significant.

$\left(n=5 ; p<0.01 ;\right.$ ANOVA; $\left.F_{(2,12)}=21.8\right)$ hyperpolarization $(88.0 \pm 3.6 \%$ of the initial response; $n=5$; Fig. $2 C)$ indicative of small, yet significant, tachyphylaxis. The 5-HT response also demonstrated a degree of dose dependence, with $1 \mu \mathrm{M} 5$-HT inducing a significant $-5.3 \pm 1.2 \mathrm{mV}(n=5, p<0.01 ; t$ test paired; $t=4.4$ ) hyperpolarization, whereas $250 \mathrm{~nm}$ failed to elicit a response $(-0.8 \pm .1 .1 ; n=5$; not significant; $t$ test paired; $t=$ 0.7; data not shown). These results demonstrate that 5-HT inhibits TIDA neurons via a direct, postsynaptic mechanism.

\section{5-HT activates a G-protein-coupled inwardly rectifying potassium (GIRK)-like current}

The ionic mechanisms underlying the 5-HT-induced hyperpolarization were investigated in voltage clamp. In the presence of TTX, application of 5-HT $(10 \mu \mathrm{M})$ resulted in a reversible outward current of $17.3 \pm 2.2 \mathrm{pA}(n=10 ; p<0.005$; ANOVA; $F_{(2,27)}=52.4$; Fig. $3 A$ ) (this value was used as a control 5-HT response for voltage-clamp tests where paired comparisons were not possible, "Control $\mathrm{I}_{5-\mathrm{HT}}$ "). Digital subtraction of voltageclamp ramps performed in control from those at the peak of response revealed the 5-HT-induced current $\left(\mathrm{I}_{5-\mathrm{HT}}\right)$ to be a net outward current (Fig. $3 \mathrm{Ai}$ ) with an estimated reversal potential of $-128.1 \mathrm{mV}$ (Fig. 3Aii), lower than that calculated for $\mathrm{K}^{+}$ $(-110.6 \mathrm{mV})$.

As this reversal potential was lower than that predicted for $\mathrm{K}^{+}$, possibly due to the role of gap junctions in the TIDA oscillation (Lyons et al., 2010) and their potential impact on space clamp, we sought to further investigate the role of $\mathrm{K}^{+}$currents in the generation of $\mathrm{I}_{5-\mathrm{HT}}$. Potassium channels were blocked through a $\mathrm{Cs}^{+}$-based internal solution. Here, 5-HT $(10 \mu \mathrm{M})$ application induced only a $5.8 \pm 0.7 \mathrm{pA}$ outward current $(n=10$; $p<0.005$; $t$ test paired; $t=-8.9$; Fig. $3 B, B i)$, a significant $66.5 \pm$ $3.8 \%$ reduction of the control 5-HT response $(n=10 ; p<0.005$ vs control $\mathrm{I}_{5-\mathrm{HT}}$; $t$ test unpaired; $t=5.1$; Fig. $\left.3 \mathrm{~A}, \mathrm{Bii}\right)$.

Next, $\left[\mathrm{K}^{+}\right]_{\mathrm{o}}$ was raised to $10 \mathrm{~mm}$, shifting the calculated $\mathrm{K}^{+}$ reversal potential to $-68 \mathrm{mV}$. At our holding potential of -60 $\mathrm{mV}$, application of 5-HT $(10 \mu \mathrm{M})$ failed to induce an outward current $(1.0 \pm 0.6 \mathrm{pA} ; n=10$; not significant; $t$ test paired; $t=$ 1.7; Fig. $3 C$ ), with $\mathrm{I}_{5-\mathrm{HT}}$ exhibiting a reversal potential of -58.9 $\mathrm{mV}$ and mild inward rectification (Fig. 3Ci).

Neuronal hyperpolarization by 5 -HT has been associated with activation of GIRK channels (Penington et al., 1993; Lüscher et al., 1997). To investigate the potential role of GIRK channels, we sequentially applied 5-HT to TIDA neurons in the absence and presence of $\mathrm{Ba}^{2+}(300 \mu \mathrm{M})$, a nonspecific blocker of inwardly rectifying $\mathrm{K}^{+}$channels. In the presence of $\mathrm{Ba}^{2+}, 5$-HT induced a $6.7 \pm 1.5 \mathrm{pA}$ outward current $(n=5 ; p<0.05$; $t$ test paired; $t=$ -4.4 ; Fig. $3 D$ ), a significant $75.1 \pm 6.5 \%$ reduction compared with the initial, $29.0 \pm 2.5 \mathrm{pA}(n=5)$, response to 5 -HT $(n=5$; $p<0.005$; ANOVA; $F_{(2,12)}=35.3$; Fig. 3Di). This reduction was not due to desensitization as following washout of 5-HT and $\mathrm{Ba}^{2+}$, reapplication of $5-\mathrm{HT}$ induced an outward current of $26.4 \pm 2.4 \mathrm{pA}(n=5 ; p<0.005 ; t$ test paired; $t=-11.1)$, which proved indistinguishable from the first response $(n=5$; not significant; ANOVA; $F_{(2,12)}=35.3$; Fig. $\left.3 \mathrm{D}, \mathrm{Di}\right)$. The selective GIRK channel blocker Tertiapin Q (TQ), a derivative of the honey bee venom tertiapin (Jin and $\mathrm{Lu}, 1999$ ), was also tested. The application of $5-\mathrm{HT}$ in the presence of TQ $(300 \mathrm{nM})$ induced a $9.5 \pm 2.2$ 
A

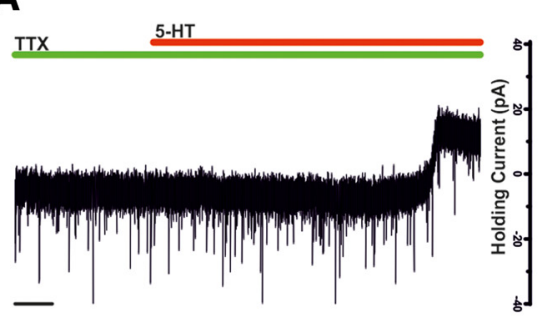

Ai

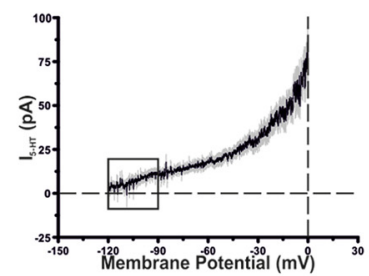

Aii

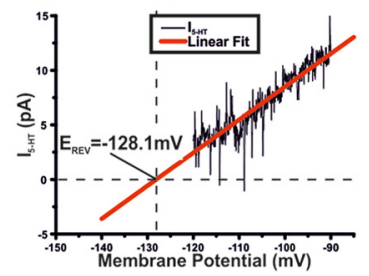

C
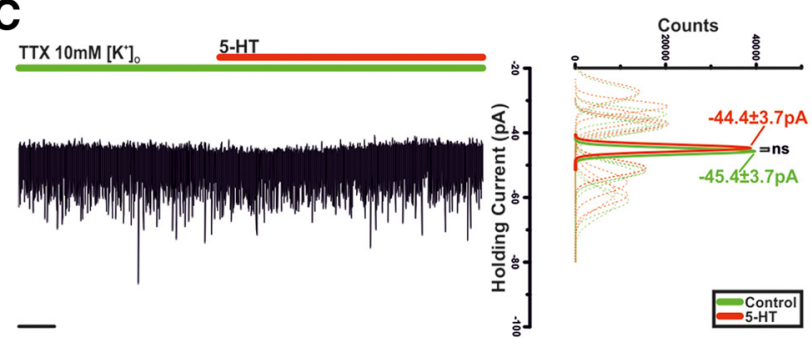

Ci

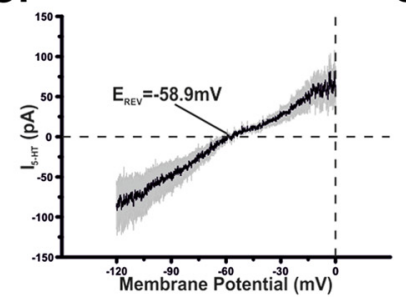

Cii

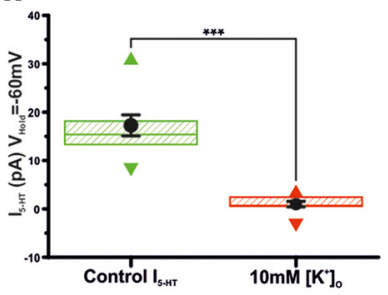

B

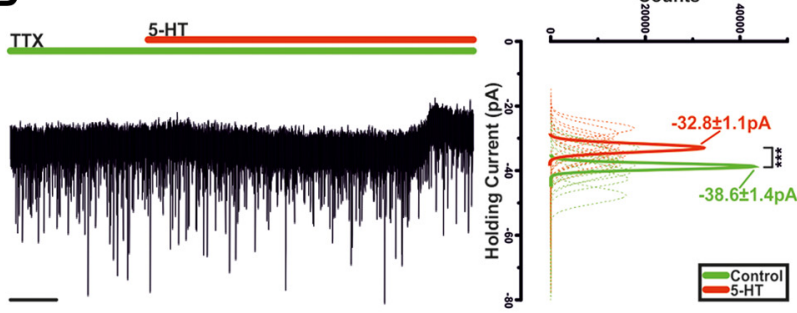

Bi

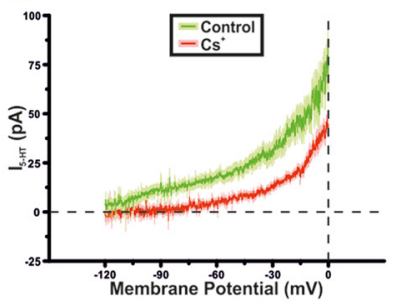

Bii

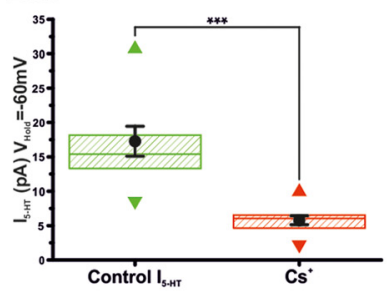

D
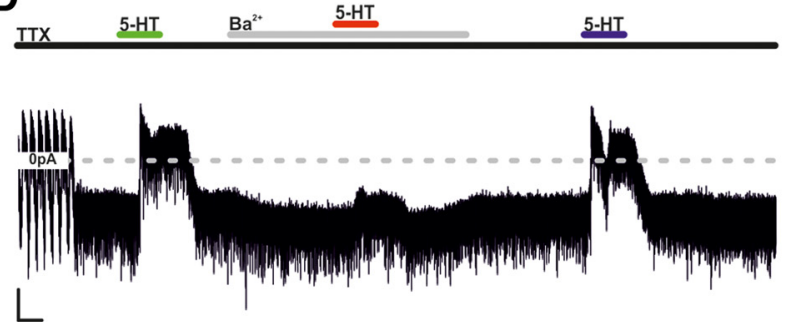

Di

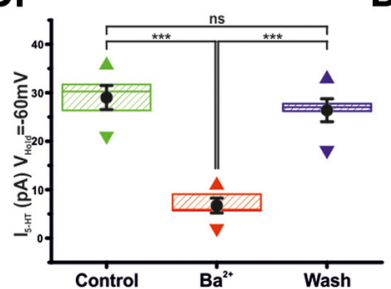

Dii

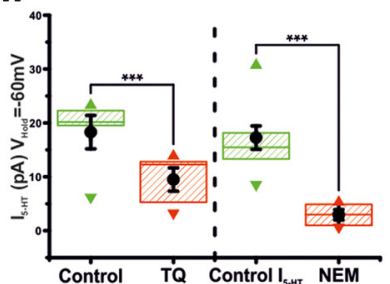

Figure 3. Serotonin activates GIRK-like channels. A, Voltage-clamp, oscillating TIDA neuron recorded in the presence of TTX. Application of 5-HT results in an outward current. Right, Gaussian fits of averaged (solid lines) holding current frequency distributions in control (green), $5-\mathrm{HT}$ (red), and wash (black) ( $n=10)$, sharing its $y$-axis with the raw trace. Dashed lines indicate raw data used to produce averages. Calibration: $5 \mathrm{~s}$. Ai, Averaged 5-HT induced current \pm SEM obtained by the digital subtraction of voltage-clamp ramps in control and at peak of 5-HT response $(n=10)$. Aii, Linear extrapolation of the 5 -HT-induced current indicated by the box in $\boldsymbol{A i}$. There is projected reversal potential $\left(\mathrm{E}_{\text {rev }}\right.$ ) of $-128.1 \mathrm{mV}$. $\boldsymbol{B}$, Voltage-clamp, oscillating TIDA neuron recorded as in Figure $3 A$, and with $\mathrm{Cs}^{+}$-based intracellular solution used to block $\mathrm{K}^{+}$-currents. Application of 5 -HT induces a substantially reduced outward current (compare $A$ ). Right, Gaussian fits of holding current frequency distributions in control (green) and 5-HT (red). $(n=10)$. Calibration: $10 \mathrm{~s}$. Bi, Averaged current-voltage relationship \pm SEM of F-HT $_{\text {in }}$ control (green, $\left.n=10\right)$ and with Cs ${ }^{+}$-based intracellular solution (red, $n=10$ ), obtained as in $\boldsymbol{A i}$. There is reduction of $\mathrm{I}_{5-\mathrm{HT}}$ when $\mathrm{Cs}^{+}$-based intracellular solution is used. Bii, Box plot of $\mathrm{I}_{5-\mathrm{HT}}$ recorded in voltage clamp with $\mathrm{CS}^{+}$-based or control intracellular solution. Boxes represent 25th, 50th, and 75th percentile with superimposed mean \pm SEM and maximum and minimum values (control $\left.n=10, \mathrm{Cs}^{+} n=10\right)$. C, Voltage-clamp, oscillating TIDA neuron recorded as in $A$ in the presence of high extracellular $\mathrm{K}^{+}$. Application of 5-HT fails to induce a significant current $(n=10)$. Calibration $5 \mathrm{~s}$. C $\mathrm{C}$, Averaged current-voltage relationship $\pm \mathrm{SEM}$ of $\mathrm{I}_{5-\mathrm{HT}}$ in the presence of High extracellular $\mathrm{K}^{+}(n=10)$, obtained as shown in $\boldsymbol{A i}$. There is a shift of the reversal potential and presence of inward rectification (compared $\boldsymbol{A i}$ ). Cii, High $\left[\mathrm{K}^{+}\right]^{0}$ significantly reduces $\mathrm{I}_{5-\mathrm{HT}}$. Box plot organized as Bii (control $n=10$, High $\left[\mathrm{K}^{+}\right]^{0} n=10$ ). $\boldsymbol{D}$, Voltage-clamp trace, oscillating TIDA neuron recorded as in $\boldsymbol{A}$ (there is abolishment of oscillation in response to TTX). 5 -HT is applied before, during, and after $\mathrm{Ba}^{+}$is present in the bath. There is Ba ${ }^{+}$-induced reduction of $\mathrm{I}_{5-\mathrm{HT}}$. Calibration: $10 \mathrm{pA}, 60 \mathrm{~s}$. Di, Ba ${ }^{+}$significantly and

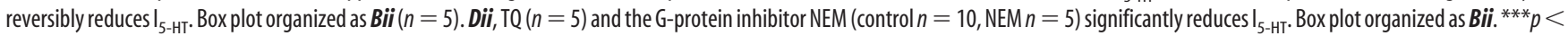
0.005. ns, Not significant.

pA outward current $(n=5 ; p<0.01, t$ test paired; $t=-4.4$ Fig. 3 Dii), a significant $48.5 \pm 6.4 \%$ reduction compared with the initial, $18 \pm 3.1 \mathrm{pA}(n=5)$, response to 5 -HT $(n=5 ; p<0.005$, $t$ test paired; $t=4.8$; Fig. $3 \mathrm{Dii})$. Furthermore, preincubation of slices (15-20 min) with the G-protein blocker N-ethylmaleimide $(\mathrm{NEM} ; 250 \mu \mathrm{M})$ resulted in an $81.9 \%$ diminution of the $5-\mathrm{HT}$ control response $\left(3.0 \pm 1.0 \mathrm{pA} ; n=5 ; p<0.005\right.$ vs control $\mathrm{I}_{5-\mathrm{HT}}$; $t$ test unpaired; $t=4.5$; Fig. $3 A, D i i)$.

Collectively these results indicate that $\mathrm{I}_{5-\mathrm{HT}}$ in TIDA neurons likely involves activation of GIRK-like channels.
5-HT inhibits TIDA neurons via the $5-\mathrm{HT}_{1 \mathrm{~A}}$ receptor

In vivo studies have implicated $5-\mathrm{HT}_{1 \mathrm{~A}}$ (Mulroney et al., 1994; Jørgensen et al., 2001), 5- $\mathrm{HT}_{2 \mathrm{~A}}$ (Liang and Pan, 2000), and $5-\mathrm{HT}_{2 \mathrm{C}}$ (Jørgensen et al., 1992) receptors in 5-HT's modulation of prolactin secretion. The broad-spectrum $5-\mathrm{HT}_{2}$ receptor antagonist methiothepin $(5 \mu \mathrm{M})$ failed to block the 5-HT-induced hyperpolarization of TIDA neurons (Control 5-HT -23.6 \pm 1.8 $\mathrm{mV}$ vs methiothepin $5-\mathrm{HT}-19.8 \pm 2.4 \mathrm{mV} ; n=3$; not significant; $t$ test paired; $t=-2.4$; data not shown). In contrast, the selective $5-\mathrm{HT}_{1 \mathrm{~A}}$ antagonist, NAD 299 ( $\left.1 \mu \mu \mathrm{M}\right)$ completely 
blocked the 5-HT-induced effect $(0.3 \pm 0.7 \mathrm{pA} ; n=12$; not significant; $t$ test paired; $t=-0.4$; Fig. $4 A$ ), a response statistically different from initial response to 5 - HT $(20.9 \pm 5.2 \mathrm{pA} ; n=12$; $p<0.005$; ANOVA; $F_{(2,33)}=25.6$; Fig. $\left.4 A i\right)$. Incubation with NAD 299 alone did not alter baseline current (Control $-15.1 \pm$ $4.1 \mathrm{pA}$ vs NAD299 $-15.0 \pm 4.2 \mathrm{pA} ; n=12$; not significant; $t$ test paired; $t=-0.17$; data not shown).

The 5- $\mathrm{HT}_{1 \mathrm{~A}}$-selective agonists, 8-OH-PIPAT and 8-OHDPAT, were also tested. Application of 8-OH-DPAT induced a $20.4 \pm 2.0 \mathrm{pA}(n=10 ; p<0.005 ; t$ test paired; $t=-10.2 ;$ Fig. $4 B)$ outward current, corresponding to $90.2 \pm 3.7 \%$ of the initial response to 5 -HT $(22.8 \pm 2.4 \mathrm{pA} ; n=10$; not significant; $t$ test; $t=1.9$; paired; Fig. 4Bi). 8-OH-PIPAT also induced an outward current that was statistically indistinguishable from the initial response to 5 -HT (Initial 5-HT $17.2 \pm 2.1 \mathrm{pA}$ vs 8 -OH-PIPAT $14.9 \pm 2.7 \mathrm{pA} ; n=5$; not significant; $t$ test paired; $t=1.6$; Fig. $4 \mathrm{C}, \mathrm{Ci}$ ). As peak response for 8-OH-PIPAT and 8-OH-DPAT often took time to stabilize and to ensure that it involved opening of GIRK-like channels, 8-OH-PIPAT was coapplied with $\mathrm{Ba}^{2+}$, under which conditions it induced a significantly reduced outward current compared with initial response to 5-HT (Initial 5-HT

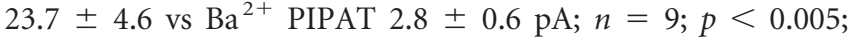
ANOVA; $F_{(2,24)}=20.2$; Fig. $\left.4 D, D i\right)$. However, subsequent removal of $\mathrm{Ba}^{2+}$ revealed the $5-\mathrm{HT}_{1 \mathrm{~A}}$-mediated outward current, which proved indistinguishable from the initial response to $5-\mathrm{HT}$ $\left(20.0 \pm 4.6 \mathrm{pA} ; n=9\right.$; not significant; $\operatorname{ANOVA} ; F_{(2,24)}=20.2$; Fig. $4 \mathrm{D}, \mathrm{Di})$. Unlike the effects of $5-\mathrm{HT}$, which were readily reversible, the response of TIDA neurons to 8-OH-PIPAT and 8-OH-DPAT did not recover in either voltage $(n=24$ of 24$)$ or current clamp ( $n=6$ of 6 ; Fig. $4 E$ ), with the $5-\mathrm{HT}_{1 \mathrm{~A}}$ agonists having been washed from the recording chamber for a minimum of $15 \mathrm{~min}$ (Fig. 4E).

\section{5-HT decreases the frequency of spontaneous and miniature IPSCs}

Having established postsynaptic effects, we investigated whether 5-HT could modulate TIDA spontaneous IPSCs (sIPSCs). Using high $\mathrm{Cl}^{-}$pipette solution and in the presence of CNQX and AP-V to block glutamatergic events, we analyzed and compared sIPSCs from a $100 \mathrm{~s}$ segment before application of 5-HT with sIPSCs from a $100 \mathrm{~s}$ segment during response. Application of 5-HT induced a reversible increase in sIPSC interevent interval (IEI; control $460.8 \pm 94.2 \mathrm{~ms}, 5-\mathrm{HT} 1935.7 \pm 358.9 \mathrm{~ms}$, washout $604.1 \pm 111.4 \mathrm{~ms} ; n=11 ; p<0.005 ; \operatorname{ANOVA} ; F_{(2,30)}=25.6$; Fig. $5 A-D)$. To determine the effect of $5-\mathrm{HT}$ on miniature IPSCs (mIPSCs), TIDA neurons were recorded as above but in the presence of TTX. Under these conditions, 5-HT did not affect mIPSC amplitude (control $60.6 \pm 5.9$ pA vs 5-HT $61.2 \pm 5.4 \mathrm{pA} ; n=5$; not significant; $t$ test paired; $t=-0.14$; Fig. $6 A-D$ ) but did increase IEI (Control $563.5 \pm 92.6 \mathrm{~ms}$ vs 5 -HT $1593.3 \pm 197.3 \mathrm{~ms} ; n=5 ; p<0.005 ; t$ test paired; $t=$ -6.8 ; Fig. $6 A-D)$. These results suggest that 5 -HT reduces GABA release onto TIDA neurons, without affecting postsynaptic responsiveness to GABA.

\section{Clinically relevant doses of fluoxetine inhibit TIDA neurons' capacity for repetitive discharge and reduce action potential (AP) amplitude}

Like 5-HT, SSRIs, such as fluoxetine (Prozac; Flx), increase plasma levels of prolactin in animals (e.g., Morgan and Herbert, 1978) and humans (e.g., Meltzer et al., 1979). Although SSRIs would, by enhancing ambient 5-HT, modulate TIDA output indirectly via the 5-HT mechanism described above, we sought to determine whether SSRIs could further modulate TIDA activity via a direct, 5-HT-independent mechanism. To this end, we again used our hypothalamic slice preparation, which, being rapidly perfused and having neither 5-HT cell bodies nor a means to stimulate deafferented 5-HT fibers, will have reduced 5-HT reuptake for SSRIs to block. As therapeutic concentrations of Flx in the brain are as high as $\sim 30 \mu \mathrm{M}$ (Karson et al., 1993), we tested TIDA neurons with prolonged $(60 \mathrm{~min})$ exposure to Flx at a concentration of $25 \mu \mathrm{M}$. In contrast to 5-HT, under this challenge, TIDA oscillations endured, undergoing only slight changes in amplitude (Control 29.20 $\pm 2.39 \mathrm{mV}$ vs Flx $60 \mathrm{~min} 23.84 \pm$ $1.74 \mathrm{mV} ; n=7 ; p<0.01$; $t$ test paired; $t=5.9$; Fig. $7 A, B)$ and frequency (Control $0.059 \pm 0.007 \mathrm{~Hz}$ vs Flx $60 \mathrm{~min} 0.072 \pm 0.005$ $\mathrm{Hz} ; n=7 ; p<0.05 ; t$ test paired; $t=-3.3$; Fig. $7 A, B)$. Intrinsic excitability was, however, severely diminished, as assessed by square-form current injection $(20 \mathrm{pA}, 500 \mathrm{~ms})$ triggered from a membrane potential of $-50 \mathrm{mV}$. Application of Flx reduced the depolarization-triggered AP number from $9.2 \pm 1.2$ to $1(n=6$; $p<0.005$; $t$ test paired; $t=7$; Fig $7 C-E$ ), most prominently after $60 \mathrm{~min}$ of drug exposure. AP waveform was also affected, with amplitude of the initial AP being reduced from $96.3 \pm 2.3 \mathrm{mV}$ in control to $31.7 \pm 3.8 \mathrm{mV}$ at $t=60 \mathrm{~min}(n=6 ; p<0.005 ; t$ test paired; $t=12.6$; Fig. $7 C, D$ ). Threshold (Control $-39.2 \pm 0.7$ $\mathrm{mV}$; Flx $60 \mathrm{~min}-33.2 \pm 1.3 \mathrm{mV} ; n=6 ; p<0.05$; $t$ test paired; $t=$ -4.3 ; Fig. 7C) and half-width (Control $1.5 \pm 0.1 \mathrm{~ms}$; Flx $60 \mathrm{~min}$ $4.6 \pm 0.5 \mathrm{~ms} ; n=6 ; p<0.005 ; t$ test paired; $t=-5.6$; Fig. $7 C$ ) were also affected.

With higher doses of Flx (100 $\mu \mathrm{M})$, voltage-clamp recordings of TIDA neurons revealed a gradual reduction in cycle amplitude and increase in cycle duration, with the oscillation being completely abolished after $28.2 \pm 3.1 \mathrm{~min}$ of continuous exposure $(n=10 / 10$; Fig. $8 A-D)$. Despite our recording conditions and use of a reduced preparation, there still remained the possibility that, rather than a 5-HT-independent effect, Flx's ability to abolish the TIDA oscillation was the consequence of either, 5-HT accumulation, or the dialysis of intracellular contents associated with prolonged whole-cell recording. To control for 5-HT accumulation, Flx was applied in the presence of NAD299, blocking 5-HT's effect at the 1A receptor (identified above as the mediator of direct electrophysiological actions of 5-HT on TIDA neurons) and presumably the effect of any increase in ambient 5-HT. These voltage-clamp recordings showed that prolonged application of Flx $(100 \mu \mathrm{M})$ still abolished the TIDA oscillation $(n=7$ of 7 ; $18.4 \pm 2.4 \mathrm{~min}$; Fig. 9A). In current clamp, Flx at the lower dose of $25 \mu \mathrm{M}$, applied in the presence of NAD299, continued to inhibit intrinsic excitability, reducing depolarization-induced AP number from $7.4 \pm 0.5$ to $1.5 \pm 0.7(n=8$; $p<0.005 ; t$ test paired; $t=6.6$; Fig. $9 B$ ). We took a number of different approaches to control for potential effects of intracellular dialysis. In the cell-attached recording configuration, thus preserving the neuron's internal milieu, Flx $(100 \mu \mathrm{M})$ also abolished TIDA AP discharge $(n=7 / 7 ; 15.1 \pm 2.1 \mathrm{~min}$; Fig. 9C). Second, whole-cell recordings of oscillating TIDA neurons were made after a $30 \mathrm{~min}$ incubation with Flx $(25 \mu \mathrm{M})$, and their intrinsic excitability was compared with TIDA neurons recorded without exposure to Flx. This challenge also saw a reduction in intrinsic excitability with depolarization-induced AP discharge decreasing from $7.0 \pm 0.6$ APs in control neurons $(n=6)$ to $1.7 \pm 0.5$ APs in Flx-incubated neurons $(n=6$; $p<0.005 ; t$ test unpaired; $t=8$; Fig. 9D). Furthermore, when performed in the whole-cell configuration, prolonged (>60 min) control voltage- and current-clamp recordings (i.e., in the absence of any drug application) demonstrated that TIDA neurons maintain their oscillations ( $n=9$ of 9 ; 
A

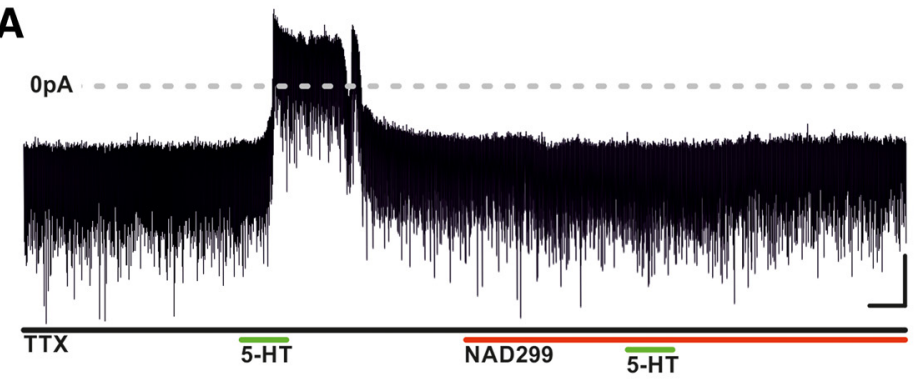

B

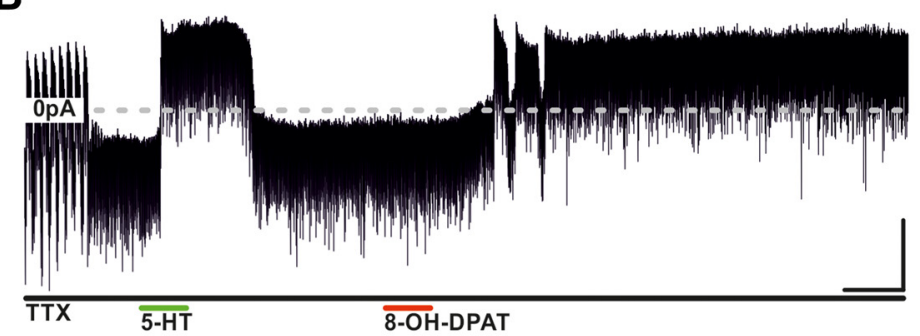

C

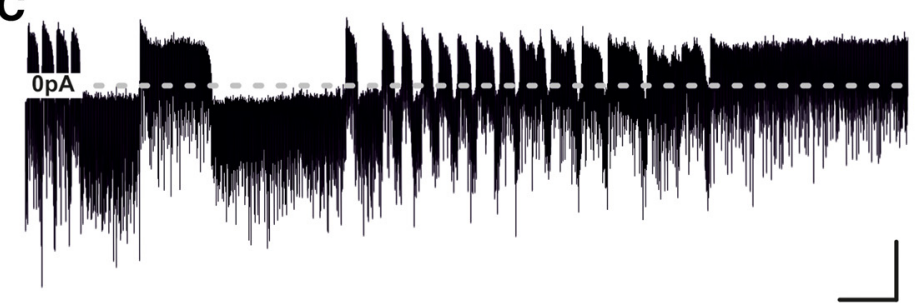

$\overline{\text { TTX } \overline{5-H T}}$

D.

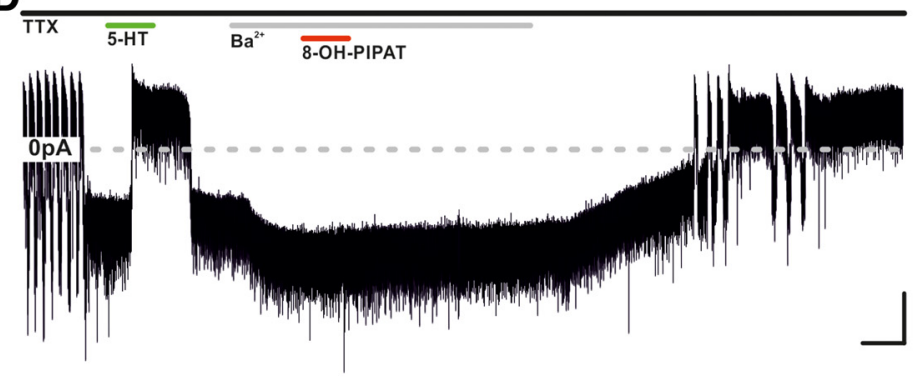

Ai

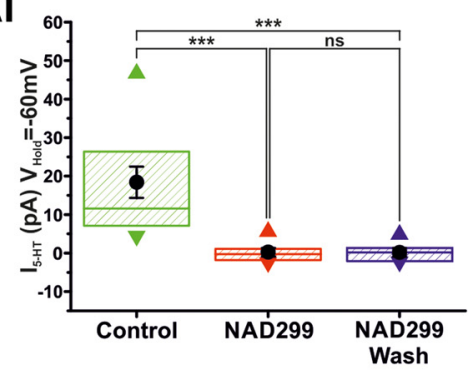

Bi

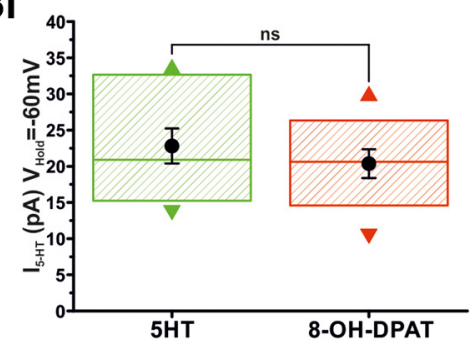

Ci

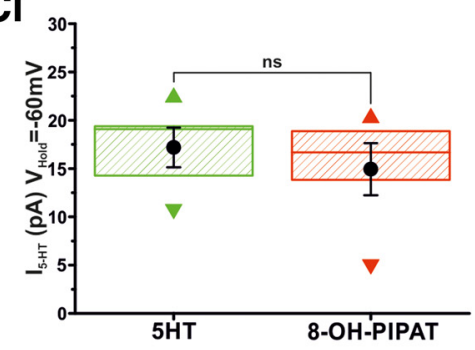

Di

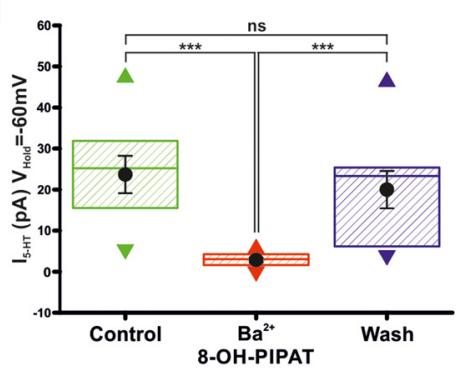

E

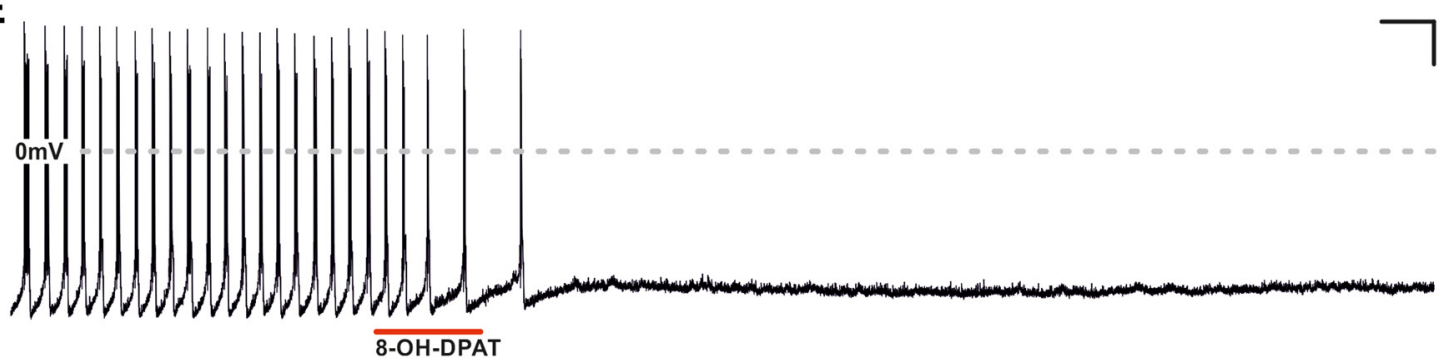

Figure 4. Serotonin inhibits TIDA neurons via activation of the 5-HT 1A receptor. A, Voltage-clamp, oscillating TIDA neuron recorded as in Figure $3 A$. 5 -HT is applied before, during, and after the 5-HT 1 A antagonist, NAD299, is present in the bath. Note the complete abolishment of 5-HT response by NAD299. Calibration: $20 \mathrm{pA}, 60 \mathrm{~s}$. Ai, Box plot organized as Figure $3 B i i$, illustrating irreversible $\mathrm{I}_{5-\mathrm{HT}}$ blockade by NAD299 $(n=12)$. B, Voltage-clamp trace, oscillating TIDA neuron recorded as in Figure 3A. Sequential application of 5-HT and the 5-HT 1 A agonist, 8-OH-DPAT; note outward current induced by both compounds. Calibration: $20 \mathrm{pA}, 60 \mathrm{~S}$. Bi, 5-HT and 8-0H-DPAT induce statistically indistinguishable outward currents in TIDA neurons. Box plot organized as Figure $3 B \mathrm{Bii}(n=10)$. $C$, Voltage-clamp trace, oscillating TIDA neuron recorded as in Figure 3A. Sequential application of 5-HT and the 5-HT 1 agonist, 8-0H-PIPAT; note outward current induced by both compounds. Calibration: 20 pA, 60 s. Ci, 5-HT and 8-OH-PIPAT induce statistically indistinguishable outward currents in TIDA neurons. Box plot organized as Figure 3Bii $(n=5)$. D, Voltage-clamp, 0scillating TIDA neuron recorded as in Figure $3 A$ (note abolishment of oscillation in response to TTX). Following a first exposure to 5 -HT, eliciting a reversible outward current, Ba ${ }^{+}(300 \mu \mathrm{M})$ is bath applied to the cell. Note the absence of a response to 8-0H PIPAT (compare $C$ in the presence of $\mathrm{Ba}^{+}$and how, as a consequence of the enduring nature of its interaction with the 5HT-1A receptor, the drug response is fully uncovered following wash of $\mathrm{Ba}^{+}$from the recording chamber. Calibration: $20 \mathrm{pA}, 60 \mathrm{~s}$. Di, $\mathrm{Ba}^{+}$significantly and reversibly reduces $\mathrm{I}_{8-\mathrm{OH}-\mathrm{PlPAT}}$. Box plot organized as Figure $3 \mathrm{Bii}$ ( $n=9$ ). $\boldsymbol{E}$, Current-clamp, application of 8-OH-PIPAT induces cessation of oscillation and AP discharge. There is lack of recovery following wash of 8-OH-PIPAT.Calibration $20 \mathrm{mV} 60 \mathrm{~s}$. ${ }^{* * *} p<0.005$. ns, Not significant. 


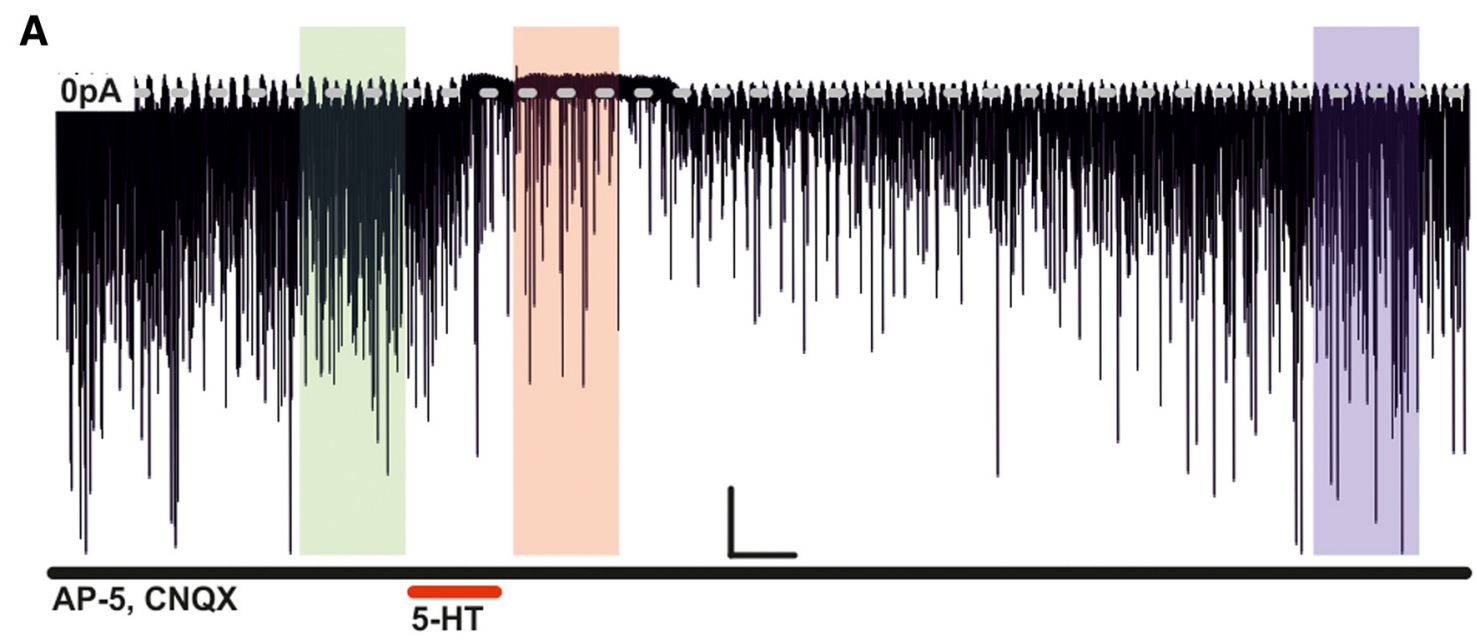

$\mathrm{Bi}$

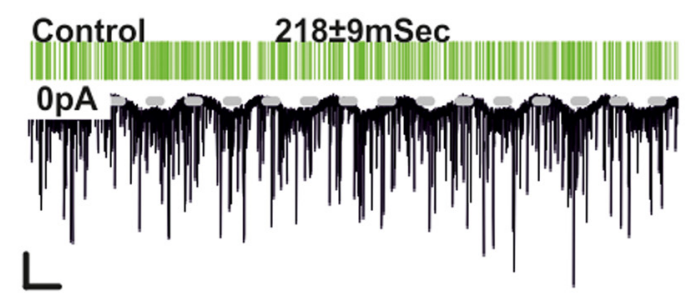

$\mathrm{Bii}$

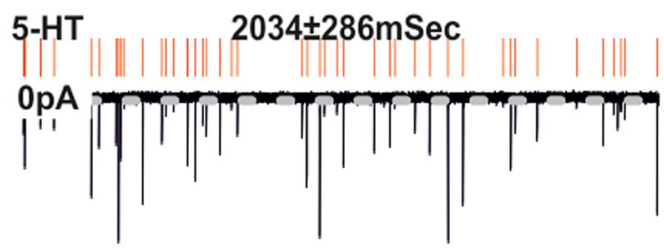

Biii

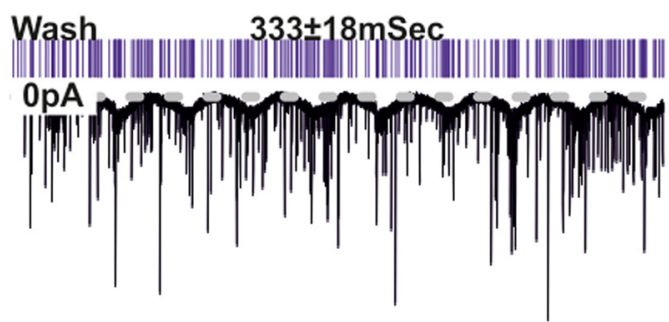

C
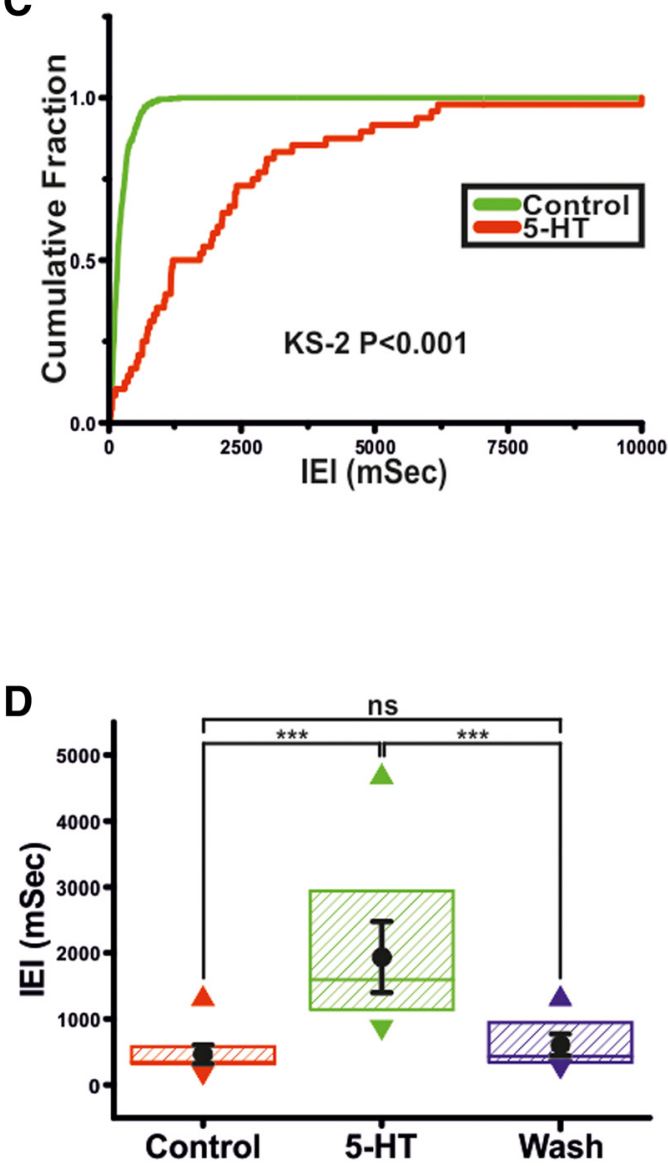

Figure 5. Serotonin inhibits sIPSCS in TIDA neurons. A, Voltage-clamp trace showing sIPSCs from an oscillating TIDA neuron, isolated pharmacologically by administration of CNQX and D-AP5 and recorded with High $\mathrm{Cl}^{-}$intracellular solution. Application of 5-HT reversibly induces an outward current and a decrease in sIPSC frequency. Calibration: $50 \mathrm{pA}, 60 \mathrm{~s}$. Bi-Biii, Enlarged views of the 100 s sections boxed in $A$ with corresponding raster plots above. Green represents Control. Red represents 5-HT. Blue represents Wash. Calibration: 50 pA, 5 s. C, Cumulative probability curves of sIPSC IEls generated from the control and 5 -HT 100 s sections boxed in A. The distribution shifts to significantly greater IEls. D, Application of 5 -HT significantly and reversibly increases the IEl of $s$ IPSCs. Box plot organized as Figure $3 \mathrm{Bii}(n=12) .{ }^{* * *} p<0.005$. ns, Not significant.

Fig. $9 E, F)$ and capacity for repetitive discharge $(n=6$ of 6 ; Fig $9 F)$. Collectively, the results from these experiments support the contention that Flx's ability to disrupt TIDA neurons' network oscillation and discharge pattern is independent of 5-HT's effects at the $1 \mathrm{~A}$ receptor and the cellular dialysis associated with wholecell recording.
SSRIs sertraline and fenfluramine also influence TIDA electrical properties

Hyperprolactinemia has been reported with the clinical use of other SSRIs, including sertraline (Petit et al., 2003) and fenfluramine (Siever et al., 1984). As with Flx, prolonged application of sertraline $(50 \mu \mathrm{M})$ induced gradual reductions in AP 
A

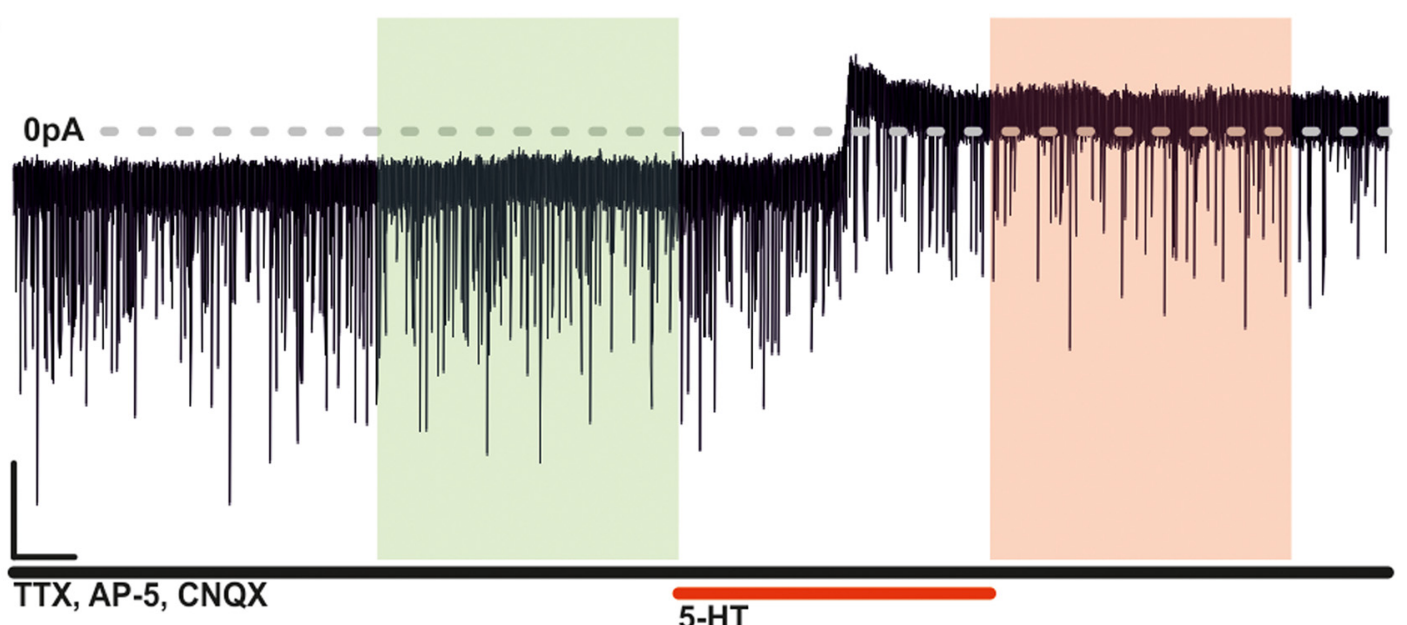

Bi

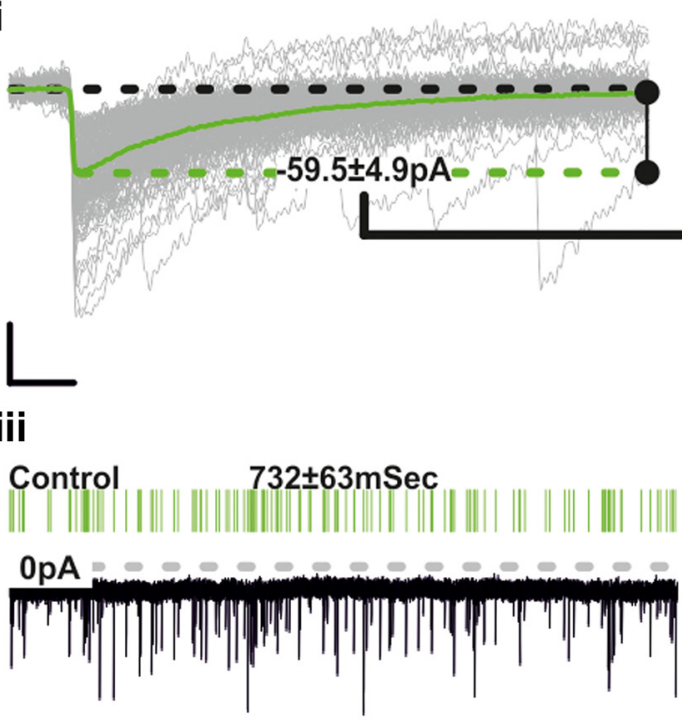

Bii

Biv

\section{5-HT}

$1720 \pm 208 \mathrm{mSec}$

$O \mathrm{pA}$

$\|$ II

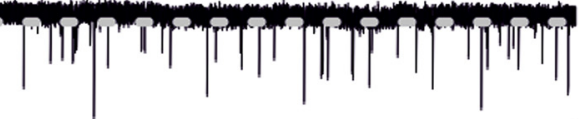

C

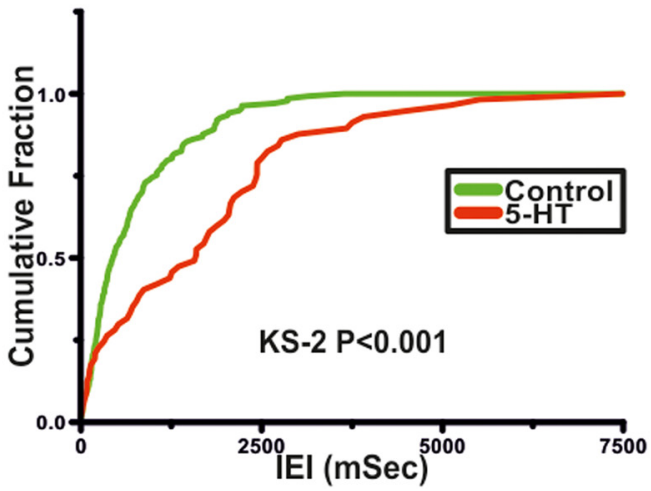

D

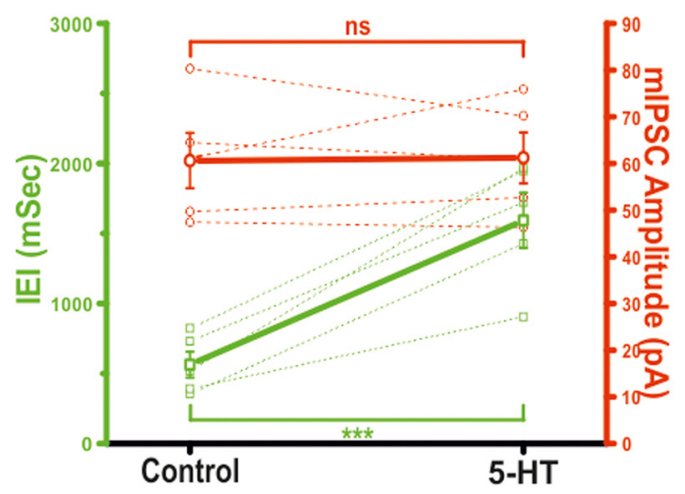

Figure 6. Serotonin inhibits mIPSCs in TIDA neurons via a presynaptic mechanism. $\boldsymbol{A}$, Voltage-clamp trace showing mIPSCs from an oscillating TIDA neuron, isolated as in Fig. $5 A$, but with TTX added to abolish AP discharge. Application of 5-HT reversibly induces an outward current and a decrease in mIPSC frequency. Calibration: 40 pA, 20 s. Bi, Bii, Rise aligned mIPSCs (gray) with averaged event superimposed from boxed areas in $\boldsymbol{A}$. Green represents Control. Red represents 5-HT. 5-HT application fails to alter mean mIPSC amplitude. Calibration: 30 pA, $10 \mathrm{~ms}$. Biii, Biv, Enlarged views of the $100 \mathrm{~s}$ sections boxed in $\boldsymbol{A}$ with corresponding raster plots above. Green represents Control. Red represents 5 -HT. Calibration: 40 pA, 5 s. $\boldsymbol{C}$, Cumulative probability curves of mIPSCIEls generated from the control (green) and $5-\mathrm{HT}$ (red) sections boxed in $\boldsymbol{A}$. The distribution shifts to significantly greater IEls (K-S2; $p<0.001$ ). $D, 5$-HT reversibly and significantly increases mIPSC IEI (green), whereas amplitude remains unchanged (red). Thick lines indicate mean \pm SEM. Dashed lines indicate raw data ( $n=5$ ). ns, Not significant.

amplitude, capacity for repetitive discharge, and oscillatory activity (Fig. 10A,B). AP number was reduced from $7.75 \pm 0.75$ to $1.75 \pm$ 0.75 per test pulse $(n=4 ; p<0.05$; $t$ test paired; $t=8.5$; AP number fell to 1 in 3 of 4 neurons tested) and amplitude of the initial AP was reduced from $93.7 \pm 2.1 \mathrm{mV}$ to $41.8 \pm 10.1 \mathrm{mV}(n=4 ; p<0.05 ; t$ test paired; $t=4.4$ ). Oscillatory activity was abolished in 4 of 4 neurons after $39.6 \pm 6.1 \mathrm{~min}$ (Fig. 10B). Fenfluramine $(20 \mu \mathrm{M})$, in contrast, abolished oscillation activity more rapidly than the other 
A

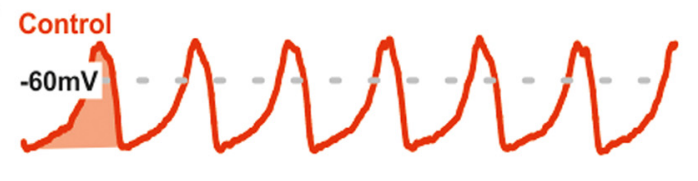

60 mins

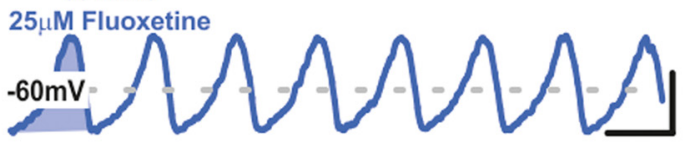

B

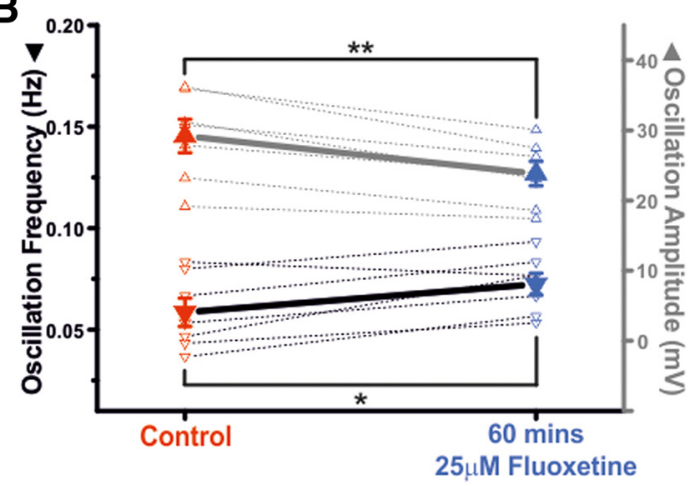

C

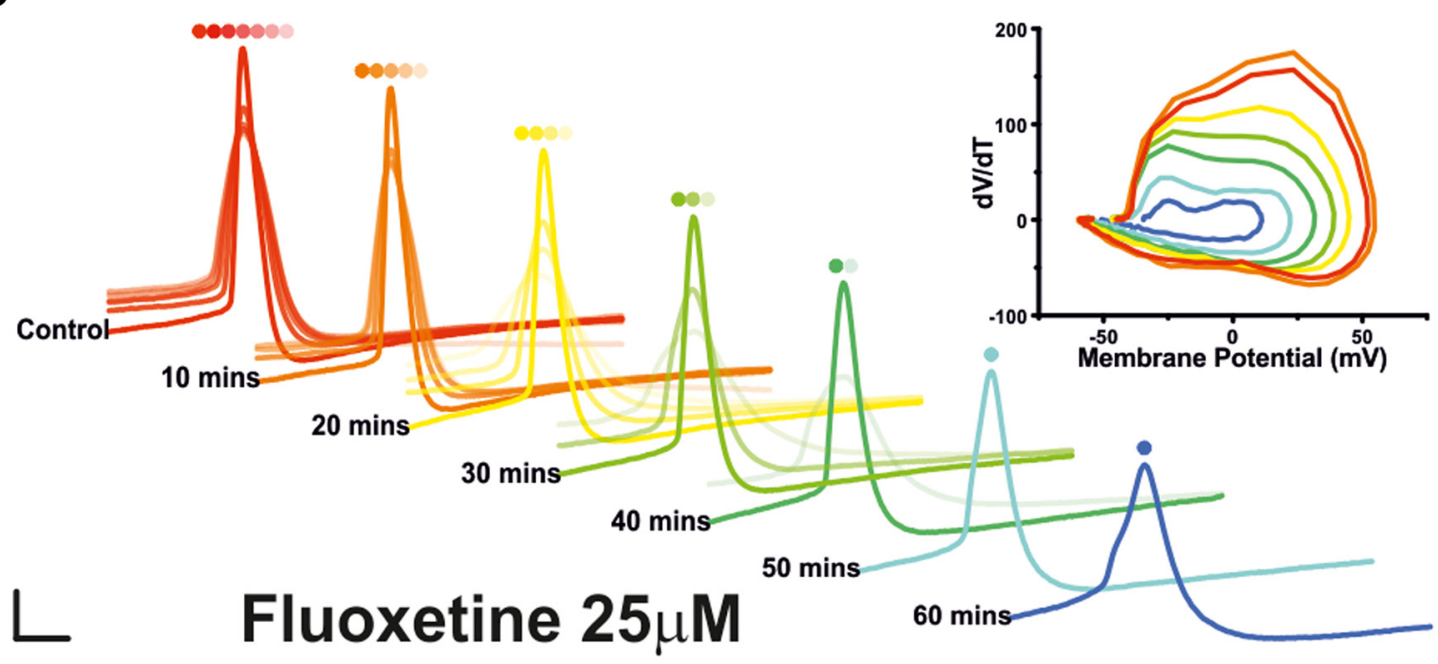

D

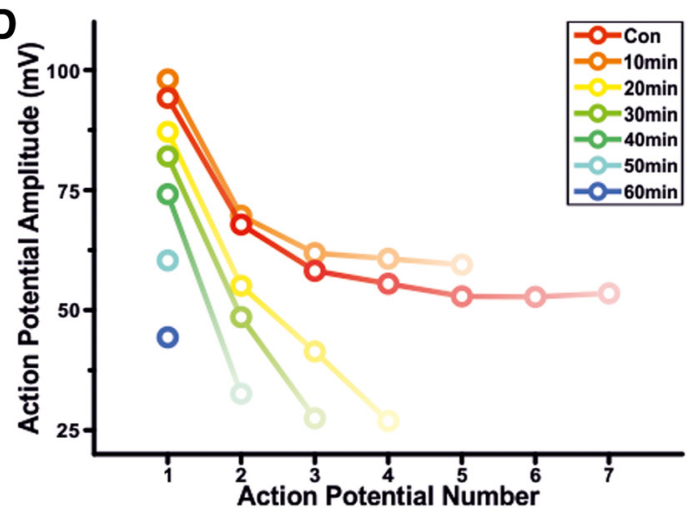

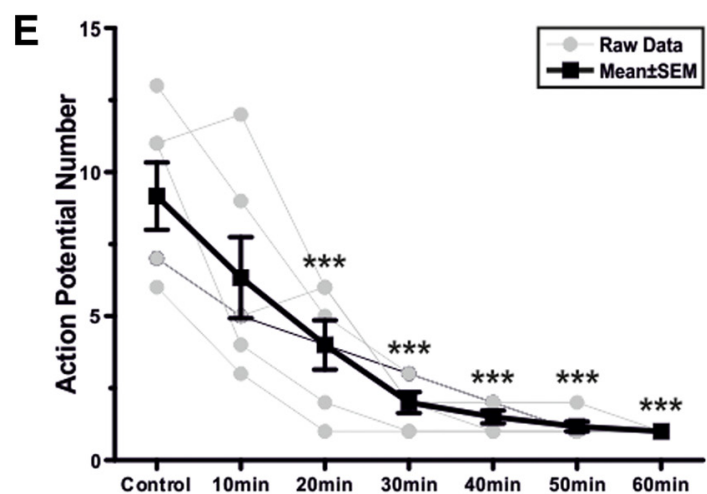

Figure 7. Clinically relevant concentrations of fluoxetine do not abolish the underlying TIDA oscillation but do inhibit TIDA neurons' capacity for repetitive discharge and reduce AP amplitude. A, Current-clamp trace of an oscillating TIDA neuron filtered at $1 \mathrm{~Hz}$ in control and following $60 \mathrm{~min}$ of $25 \mu \mathrm{m}$ fluoxetine. Calibration $20 \mathrm{mV} 20 \mathrm{~s}$. B, Summary of fluoxetine-induced effects on oscillation amplitude (gray) and frequency (black). Thick lines indicate mean \pm SEM. Dashed lines indicate raw data $(n=7)$. C, Peak aligned APs elicited in response to a square-form-positive current pulse during $60 \mathrm{~min}$ application of $25 \mu \mathrm{m}$ fluoxetine. There is progressive reduction in AP number and amplitude. Calibration: $16 \mathrm{mV}, 4 \mathrm{~ms}$. Inset, Orbital plots of the first AP highlight change in threshold, amplitude, and rise and decay time. $\boldsymbol{D}$, Plot showing AP number and amplitude data from the cell depicted in $\boldsymbol{A}$. $\boldsymbol{E}$, Fluoxetine progressively inhibits TIDA neurons' capacity for repetitive discharge. Thick lines indicate mean \pm SEM. Thin lines indicate raw data $(n=6) .{ }^{*} p<0.05$. ${ }^{* *} p<0.01$. ${ }^{* * *} p<0.005$.

SSRIs tested $\left(11.6 \pm 2.6 \mathrm{~min} ; n=5 ; p<0.05 ;\right.$ ANOVA; $F_{(2,11)}=$ 11.0; Fig. 10C,D) but following 60 min of exposure did not significantly reduce either AP number $(5.3 \pm 0.7$ in control, $3.3 \pm 1.5$ in fenfluramine; $n=3$; not significant; $t$ test paired, $t=1.3$ ) or the amplitude of the initial AP $(99.3 \pm 3.8 \mathrm{mV}$ in control, $87.0 \pm 7.2 \mathrm{mV}$ in fenfluramine; $n=3$; not significant; $t$ test paired; $t=3$ ).

\section{Discussion}

The ability of 5-HT and SSRIs to stimulate prolactin release was first described $>40$ years ago (Lu and Meites, 1973; Emiliano and Fudge, 2004). The hyperprolactinemia induced by many SSRIs has been linked to the sexual side effects associated with these 


\section{A}

\section{Fluoxetine $100 \mu \mathrm{M}$}

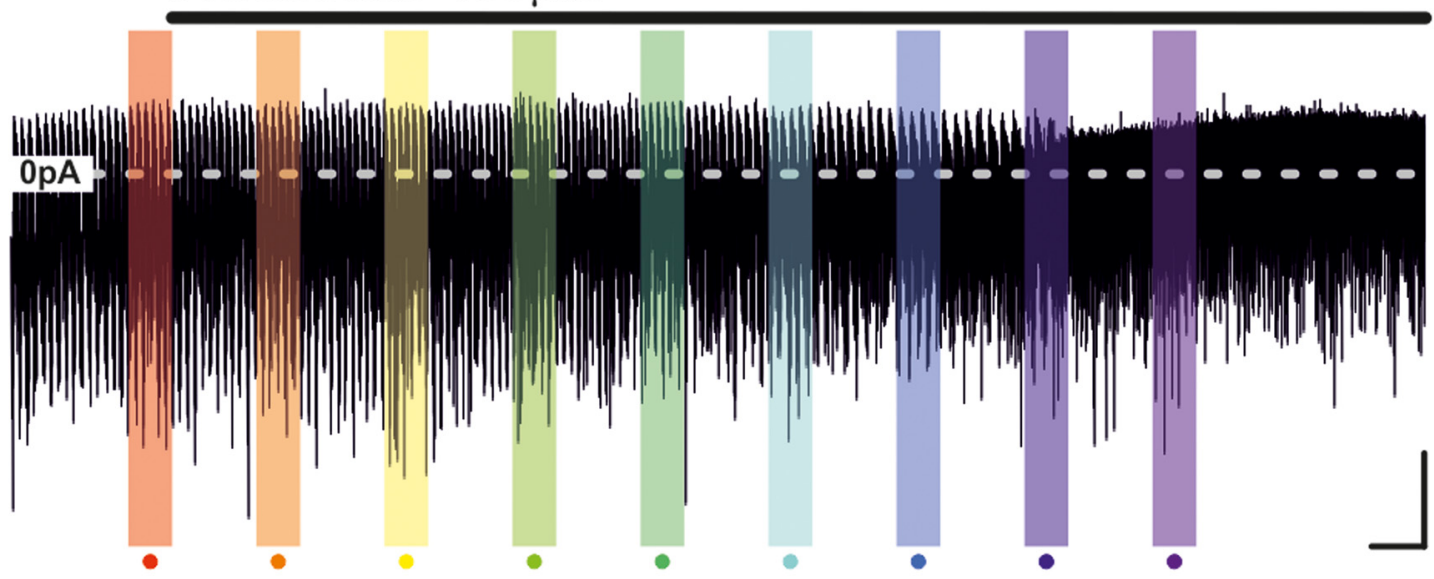

B

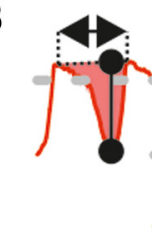

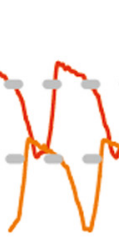

Din

D

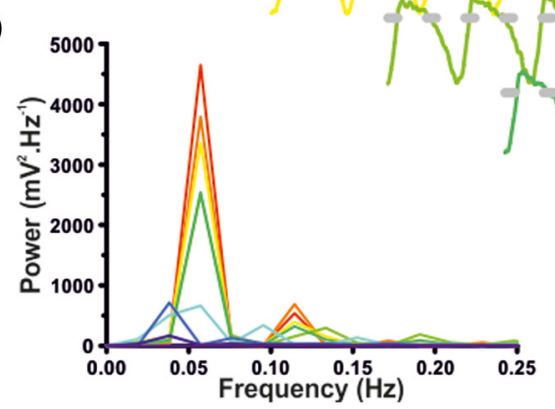

C

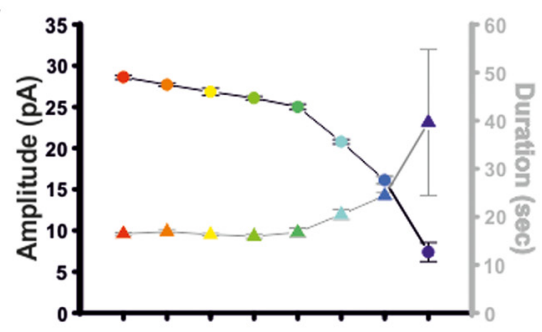

Figure 8. Supraclinical concentrations of fluoxetine abolish the TIDA oscillation. $\boldsymbol{A}$, Voltage-clamp trace of an oscillating TIDA neuron. Application of $100 \mu \mu$ fluoxetine gradually abolishes TIDA oscillation. Calibration: 20 pA, 2 min. $\boldsymbol{B}$, Enlarged color-coded $100 \mathrm{~s}$ boxed sections in $\boldsymbol{D}$ filtered at $1 \mathrm{~Hz}$. There is gradual reduction in oscillation amplitude and frequency. Calibration: $10 \mathrm{pA}$, $5 \mathrm{~s}$. $\boldsymbol{C}$, Average oscillation cycle amplitude and duration from the color-coded data depicted in $\boldsymbol{B}$. D, Spectral density plots of the color-coded data depicted in $\boldsymbol{B}$. There is successively reduced oscillation strength and peak frequency.

drugs (Urban and Veldhuis, 1991; Amsterdam et al., 1997; Ekselius et al., 1997), which are common and sufficiently debilitating to cause drug withdrawal in many patients (Montejo et al., 2001; van Geffen et al., 2007). Yet, how 5-HT and SSRIs stimulate prolactin release is not well understood. Here we show that 5-HT activates a $\mathrm{K}^{+}$conductance to directly hyperpolarize and inhibit the firing of rat TIDA neurons in vitro. We further show that fluoxetine and sertraline also decrease TIDA excitability, but that the cellular mechanisms, as revealed by recordings in a deafferented slice preparation lacking serotonergic neurons and in the continued presence of the 5- $\mathrm{HT}_{1 \mathrm{~A}}$ antagonist NAD299, are likely different from those through which 5-HT acts.

The outward current activated by $5-\mathrm{HT}$ was mimicked by application of 8-OH-PIPAT and 8-OH-DPAT and was blocked by prior application of NAD299, indicating that it is mediated by $5-\mathrm{HT}_{1 \mathrm{~A}}$ receptors. $\mathrm{I}_{5-\mathrm{HT}}$ displays characteristics of a GIRK current with its hyperpolarized reversal potential, inward rectification, sensitivity to $\left[\mathrm{Cs}^{+}\right]_{\mathrm{i}}$ and $\left[\mathrm{K}^{+}\right]_{\mathrm{o}}$, and inhibition by $\mathrm{Ba}^{2+}$, the GIRK blocker, TQ, and the G-protein uncoupling agent, NEM. A GIRK-like current modulated by opioid and $\mathrm{GABA}_{\mathrm{B}}$ agonists has been described in TIDA neu- rons (Loose et al., 1990), and GIRK channel subunits are strongly expressed in the arcuate nucleus (Saenz del Burgo et al., 2008). Moreover, coupling of the $5-\mathrm{HT}_{1 \mathrm{~A}}$ receptor to GIRK channels has previously been reported in hippocampal (Lüscher et al., 1997) and raphe (Penington et al., 1993) neurons, and mRNAs encoding these proteins are frequently coexpressed (Saenz del Burgo et al., 2008).

We thus propose that 5-HT-induced hyperpolarization, underpinned by a $5-\mathrm{HT}_{1 \mathrm{~A}}$ receptor-mediated opening of GIRK-like channels, abolishes TIDA neuron discharge, which in turn reduces dopamine release in the portal capillaries. As such, the inhibitory D2R "brake" on lactotrophs is relieved, resulting in the secretion of prolactin into the general circulation. This scenario is in agreement with reports that 5-HT agonists, at concentrations that stimulate prolactin release, decrease the levels of dopamine in the TIDA-pituitary axis (Pilotte and Porter, 1981) and fail to increase prolactin when dopamine synthesis has been blocked (Quattrone et al., 1979). There is also evidence that 5-HT stimulates the release of a prolactin-releasing factor (Clemens et al., 1978; Pilotte and Porter, 1981), possibilities that are not mutually exclusive. 


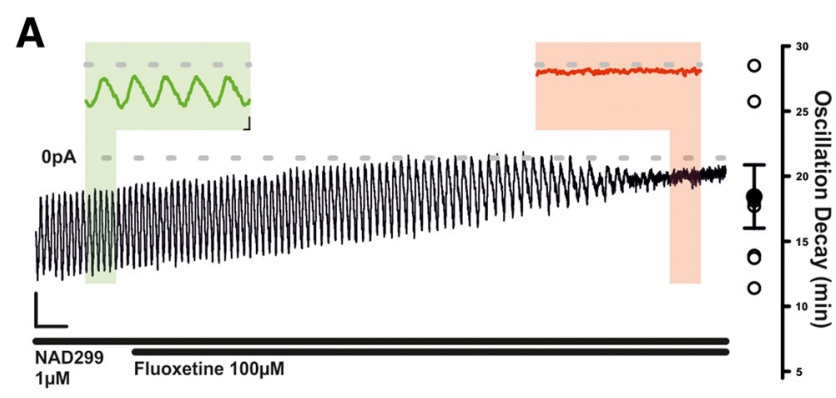

B

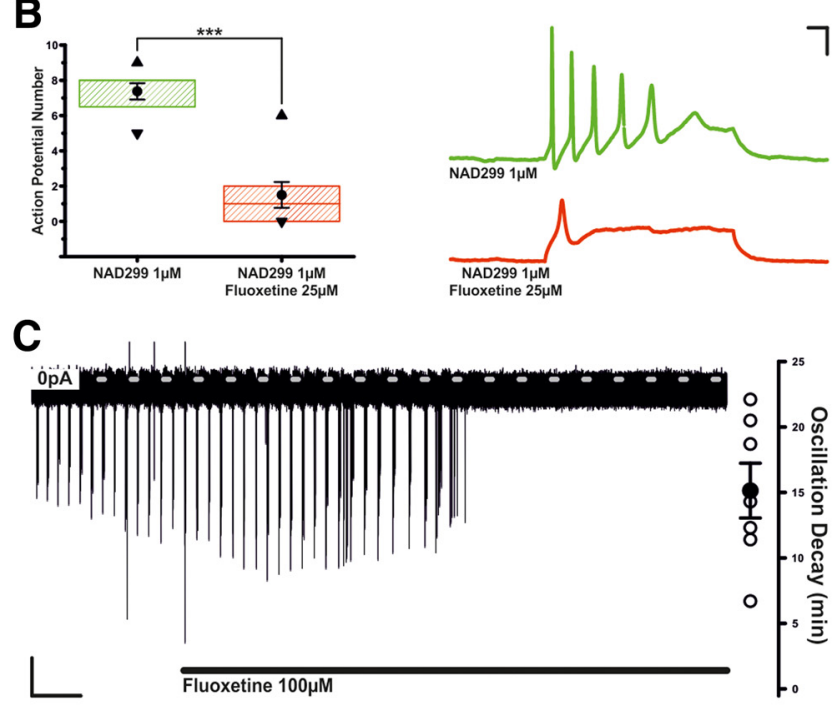

D

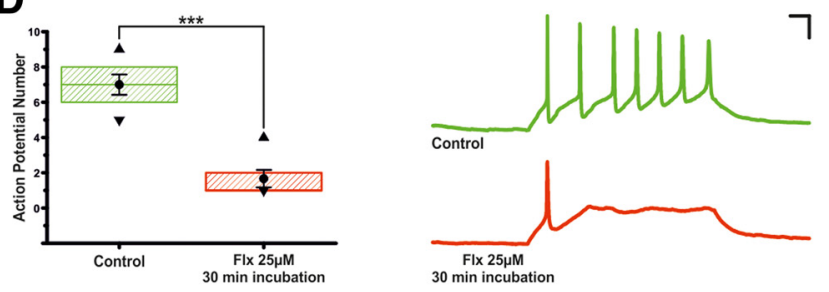

$\mathbf{E}$

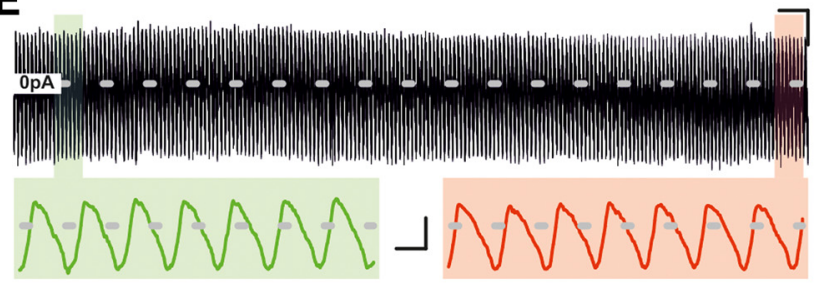

$\mathbf{F}$
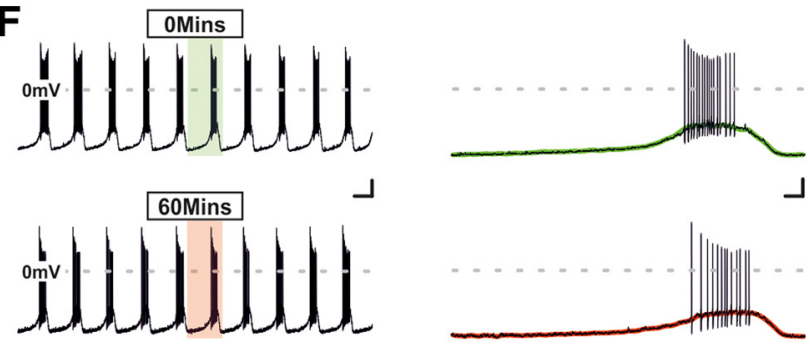

Figure 9. Fluoxetine's effects upon TIDA oscillation and repetitive discharge are independent of $5-\mathrm{HT}_{1 \mathrm{~A}}$ receptor activation and intracellular dialysis. $\boldsymbol{A}$, Voltage-clamp trace of an oscillating TIDA neuron filtered at $1 \mathrm{~Hz}$. Application of $100 \mu \mathrm{m}$ fluoxetine continues to abolish TIDA oscillation despite the continuous presence of the $5-\mathrm{HT}_{1 \mathrm{~A}}$ receptor antagonist, NAD299. Calibration: 10 pA, 60 s. Inset, Enlarged areas of $\boldsymbol{A}$ denoted by color. Calibration: Inset, 10 pA, 2 s. $\boldsymbol{B}$, Fluoxetine continues to inhibit TIDA neuron's capacity for repetitive discharge, reducing the
The persistence of the 5-HT-induced hyperpolarization in the presence of TTX and the presence of 5-HT terminals on TIDA cell bodies (confirming Bosler et al., 1984; Kiss and Halász, 1986) demonstrates direct, postsynaptic actions of 5-HT on TIDA cells. We also show, however, a decrease in presynaptic inhibitory inputs in response to 5-HT. This finding is perhaps best explained by anatomical evidence that TIDA neurons are GABAergic (Everitt et al., 1984) and may auto-innervate (Léránth et al., 1985), and also indicates the existence of 5-HT receptors on the axon terminal as well as the somatodendritic compartment of TIDA neurons. Thus, the loss of IPSCs may primarily reflect abolishment of TIDA discharge, further attesting to the powerful inhibition of the system by $5-\mathrm{HT}$. Modulation of nonTIDA-derived GABAergic input by 5 -HT can, however, not be excluded.

Fluoxetine and other SSRIs were developed based on the hypothesis that hypoactivity of central serotonergic transmission underlies depression (see Wong et al., 1995). Given Flx's proven ability to increase ambient 5-HT, its prolactin-releasing effects in the whole animal would then be expected to depend on serotonin's ability to inhibit TIDA output. Accordingly, in a situation with little or no 5-HT release or accumulation (such as in our deafferented, rapidly perfused slice), or in the continued presence of the $5-\mathrm{HT}_{1 \mathrm{~A}}$ antagonist NAD299, SSRIs would fail to inhibit TIDA neurons. However, this was clearly not the case, as during exposure to clinically relevant concentrations $(25 \mu \mathrm{M})$ (Karson et al., 1993) of Flx, the intrinsic excitability of TIDA neurons was powerfully blunted with decreased AP amplitude and reduced capacity for repetitive discharge. Notably, however, the oscillation as such persisted, in sharp contrast to its abolishment in the presence of 5-HT. At $100 \mu \mathrm{M} \mathrm{Flx}$, the oscillation disappeared, but with a strikingly different temporal profile to 5 -HT, a response preserved despite $5-\mathrm{HT}_{1 \mathrm{~A}}$ receptor blockade. Furthermore, similar effects were seen with sertraline and fenfluramine.

How can these apparently 5-HT-independent effects be explained? A solution can be found in the accumulating evidence for off-target (i.e., nonserotonergic) actions of SSRIs documented in the literature (see Bianchi, 2008). Studies in other systems have revealed that Flx can directly modulate particular membrane currents, including those carried by $\mathrm{K}^{+}$(e.g., Tytgat et al., 1997), $\mathrm{Ca}^{2+}$ (e.g., Deák et al., 2000), and $\mathrm{Cl}^{-}$(e.g., Steele et al., 2005). Of particular relevance to the present results, Flx has been shown to attenuate both persistent $\left(\mathrm{I}_{\mathrm{NaP}}\right)$ and transient sodium currents $\left(\mathrm{I}_{\mathrm{NaT}}\right)$, inhibiting repetitive discharge and oscillatory activity in olfactory bulb neurons with a

$\leftarrow$

number of APs in response to depolarizing current injection. Box plot organized as Figure 3Bii $(n=8)$. Right, Current-clamp traces showing the voltage response and AP discharge elicited by injection of a fixed-amplitude positive current pulse during control (green) and during application of fluoxetine $(25 \mu \mathrm{m})$. Calibration: $20 \mathrm{mV}, 50 \mathrm{~ms}$. C, Cell-attached recording of an oscillating TIDA neuron. Fluoxetine $(100 \mu \mathrm{m})$ continues to abolish the TIDA oscillation when intracellular contents remain undisturbed. Calibration: 10 pA, 2 min. D, Oscillating TIDA neurons patch clamped in whole-cell configuration following preincubation (30 min) with $25 \mu \mathrm{m}$ fluoxetine (red) also exhibit reduced capacity for repetitive discharge, compared with TIDA neurons that have not been exposed to fluoxetine (green). Box plot organized as Figure $3 B i i(n=6)$. Right Traces organized as in $\boldsymbol{B}$. Calibration: $20 \mathrm{mV}, 50 \mathrm{~ms}$. $\boldsymbol{E}$, Voltage-clamp trace of oscillating TIDA neuron. The $60 \mathrm{~min}$ of prolonged recording and intracellular dialysis fails to abolish the TIDA oscillation. Calibration: 20 pA, 2 min. Inset, Expanded areas of $\boldsymbol{E}$ denoted by color, filtered at 1 Hz. Calibration: Inset, 20 pA, 10 s. $\boldsymbol{F}$, Current-clamp recording of an oscillating TIDA neuron at $t=0$ and $t=60 \mathrm{~min}$. The $60 \mathrm{~min}$ of prolonged recording fails to abolish TIDA neuron's capacity for repetitive discharge. Calibration: $20 \mathrm{mV}, 10 \mathrm{~s}$. Inset, Enlarged areas of $\boldsymbol{F}$ overlaid with trace filtered at $1 \mathrm{HZ}$ according to color. Calibration: Inset, $20 \mathrm{mV}$, 1 s. ${ }^{* * *} p<0.005$. 
A

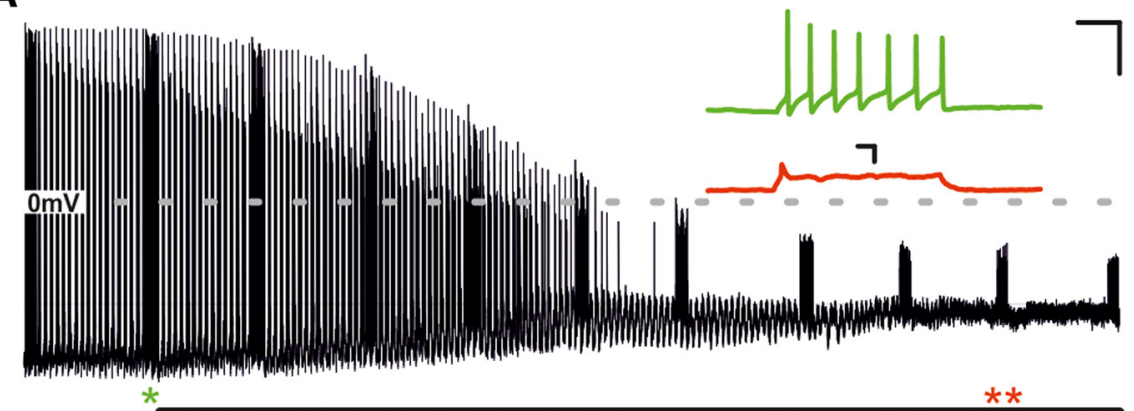

Sertraline $50 \mu \mathrm{M}$

B

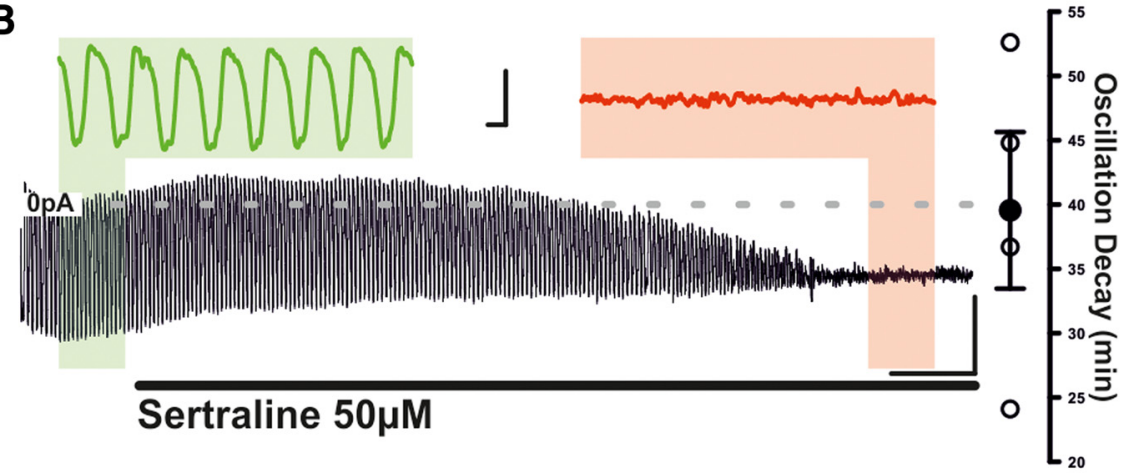

C

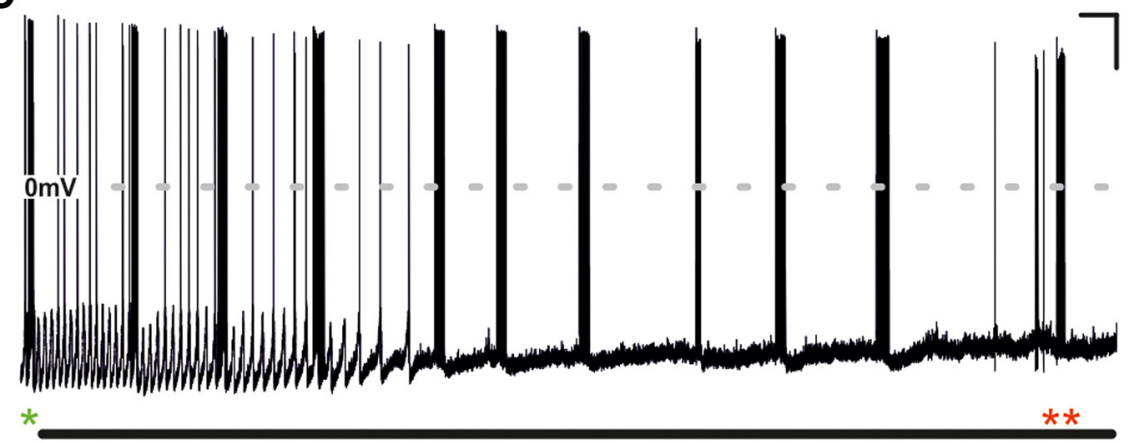

Fenfluramine $20 \mu \mathrm{M}$

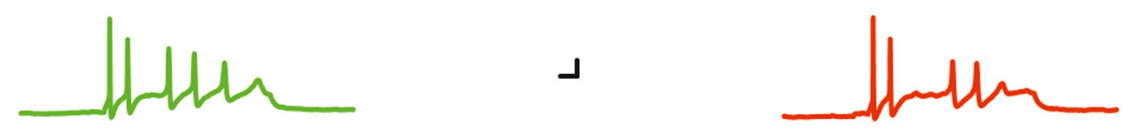

D

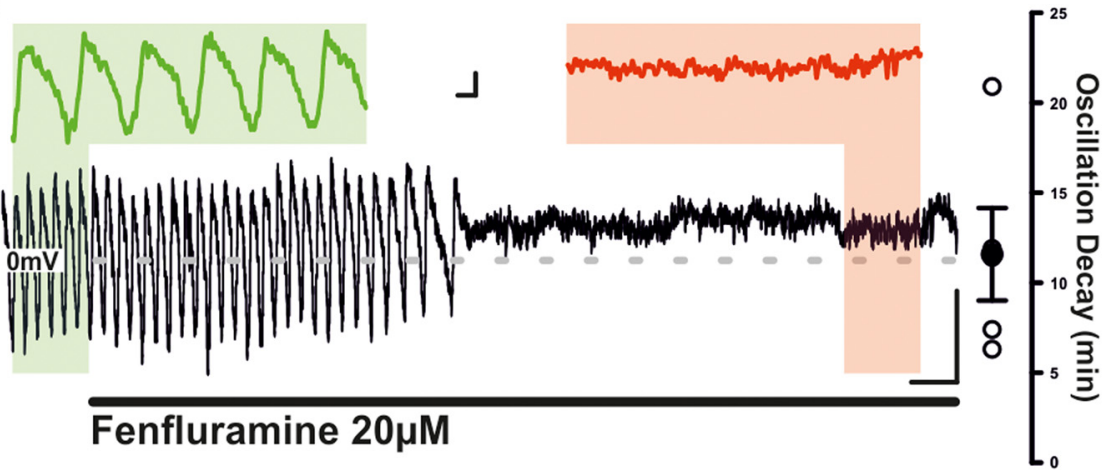

Figure 10. Sertraline abolishes both the TIDA oscillation and capacity for repetitive discharge, whereas fenlfuramine abolishes the TIDA oscillation but leaves the capacity for repetitive discharge intact. $A$, Current-clamp recording of an oscillating TIDA neuron. The response of the cell to injection of square-form-positive current pulses of constant size is tested at regular intervals (e.g., at asterisks). Prolonged bath application of sertraline results in gradual abolishment of oscillatory activity and reduction time course very similar to that shown here (Igelström and Heyward, 2012). In TIDA neurons, $\mathrm{I}_{\mathrm{NaP}}$ is an important contributor to regenerative firing, as evidenced by the abolishment of oscillatory activity by the $\mathrm{I}_{\mathrm{NaP}}$ blocker TTX, independent of this compound's effects on presynaptic input (Lyons et al., 2010; and unpublished observations). Thus, the decreased intrinsic excitability observed in TIDA neurons after application of Flx and sertraline may be due to inhibitory actions of these drugs on $\mathrm{I}_{\mathrm{NaP}}$. (It may be noted, in this context, that fenfluramine, which in addition to suppressing reuptake also stimulates nonexocytotic release of 5-HT [Kannengiesser et al., 1976], exerted an effect on a timescale more akin to 5-HT).

Thus, we propose that SSRIs promote prolactin release in vivo through two distinct actions on the TIDA network, both resulting in decreased DA output. First, by increasing 5-HT tone, SSRIs promote $5-\mathrm{HT}_{1 \mathrm{~A}} / \mathrm{GIRK}$-mediated hyperpolarization. Second, in a 5HT-independent manner, SSRIs reduce TIDA intrinsic excitability by inhibiting oscillatory activity and AP discharge, via reductions in $\mathrm{I}_{\mathrm{NaT}}$ and $\mathrm{I}_{\mathrm{NaP}}$, respectively. Combined, these actions would result in a shutdown of the TIDA system, causing an increase in prolactin secretion. The present data thus highlight a novel mechanism for the hyperprolactinemia and sexual side effects of SSRIs. It should be noted that acute drug applications to slice preparations of TIDA from the young male rat offers far from a perfect model of the clinical situation where SSRIs are prescribed for long periods to a large and heterogeneous pop-

\section{$\leftarrow$}

in AP amplitude and number, as well as of spontaneous discharge. Calibration: $20 \mathrm{mV}, 2 \mathrm{~min}$. Inset, Expanded sections from $\boldsymbol{A}$ denoted by asterisks. Calibration: Inset, $20 \mathrm{mV}, 50 \mathrm{~ms}$. $B$, Voltage-clamp recording of a TIDA neuron filtered at $1 \mathrm{~Hz}$. Prolonged sertraline exposure results in a gradual amplitude reduction and eventual abolishment of oscillation. Calibration: $20 \mathrm{pA}, 4 \mathrm{~min}$. Inset, Expanded areas of $\boldsymbol{B}$ according to color. Calibration: Inset, $20 \mathrm{pA}, 5$ s. C, Current-clamp recording of an oscillating TIDA neuron. The response of the cell to injection of square-form-positive current pulses of constant size is tested at regular intervals (e.g., at asterisks). Prolonged bath application of fenfluramine results in gradual abolishment of oscillatory activity but fails to reduce capacity for repetitive discharge. Calibration: $20 \mathrm{mV}, 2 \mathrm{~min}$. Inset, Expanded sections from C denoted by asterisks. Calibration: Inset, $20 \mathrm{mV}, 50 \mathrm{~ms}$. D, Voltage-clamp recording of a TIDA neuron filtered at $1 \mathrm{~Hz}$. Prolonged fenfluramine exposure results in a gradual amplitude reduction and eventual abolishment of oscillation. Calibration: $5 \mathrm{pA}, 1 \mathrm{~min}$. Inset, Expanded areas of $\boldsymbol{D}$ according to color. Calibration: Inset, $2 \mathrm{pA}, 4 \mathrm{~s} .{ }^{* *} p<0.01$. 
ulation for several diagnoses. The ability of these compounds to elevate circulating prolactin is also less robust when assessed in human subjects than in inbred experimental rodents. Yet, hyperprolactinemia, as well as adverse reproductive effects, are notably common when rigorously assessed in SSRItreated patients (Montejo-González et al., 1997; Clayton et al., 2002). Thus, these results may be of importance for the development of antidepressant therapies with minimized reproductive side effects and consequently enhanced patient compliance.

\section{References}

American Psychiatric Association (2000) Practice guideline for the treatment of patients with major depressive disorder (revision). Am J Psychiatry 157[Suppl]:1-45. CrossRef Medline

Amsterdam JD, Garcia-España F, Goodman D, Hooper M, Hornig-Rohan M (1997) Breast enlargement during chronic antidepressant therapy. J Affect Disord 46:151-156. CrossRef Medline

Bianchi MT (2008) Non-serotonin anti-depressant actions: direct ion channel modulation by SSRIs and the concept of single agent poly-pharmacy. Med Hypotheses 70:951-956. CrossRef Medline

Birge CA, Jacobs LS, Hammer CT, Daughaday WH (1970) Catecholamine inhibition of prolactin secretion by isolated rat adenohypophyses. Endocrinology 86:120-130. CrossRef Medline

Bole-Feysot C, Goffin V, Edery M, Binart N, Kelly PA (1998) Prolactin (PRL) and its receptor: actions, signal transduction pathways and phenotypes observed in PRL receptor knockout mice. Endocr Rev 19:225-268. CrossRef Medline

Bosler O, Joh TH, Beaudet A (1984) Ultrastructural relationships between serotonin and dopamine neurons in the rat arcuate nucleus and medial zona incerta: a combined radioautographic and immunocytochemical study. Neurosci Lett 48:279-285. CrossRef Medline

Briffaud V, Williams P, Courty J, Broberger C (2015) Excitation of tuberoinfundibular dopamine neurons by oxytocin: crosstalk in the control of lactation. J Neurosci 35:4229-4237. CrossRef Medline

Buvat J, Lemaire A, Buvat-Herbaut M, Fourlinnie JC, Racadot A, Fossati P (1985) Hyperprolactinemia and sexual function in men. Horm Res 22: 196-203. CrossRef Medline

Clayton AH, Pradko JF, Croft HA, Montano CB, Leadbetter RA, BoldenWatson C, Bass KI, Donahue RM, Jamerson BD, Metz A (2002) Prevalence of sexual dysfunction among newer antidepressants. J Clin Psychiatry 63:357-366. CrossRef Medline

Clemens JA, Roush ME, Fuller RW (1978) Evidence that serotonin neurons stimulate secretion of prolaction releasing factor. Life Sci 22:2209-2213. CrossRef Medline

Deák F, Lasztóczi B, Pacher P, Petheö GL, Valéria Kecskeméti, Spät A (2000) Inhibition of voltage-gated calcium channels by fluoxetine in rat hippocampal pyramidal cells. Neuropharmacology 39:1029-1036. CrossRef Medline

Ekselius L, von Knorring L, Eberhard G (1997) A double-blind multicenter trial comparing sertraline and citalopram in patients with major depression treated in general practice. Int Clin Psychopharmacol 12:323-331. CrossRef Medline

Emiliano AB, Fudge JL (2004) From galactorrhea to osteopenia: rethinking serotonin-prolactin interactions. Neuropsychopharmacology 29: 833-846. CrossRef Medline

Everitt BJ, Hökfelt T, Wu JY, Goldstein M (1984) Coexistence of tyrosine hydroxylase-like and gamma-aminobutyric acid-like immunoreactivities in neurons of the arcuate nucleus. Neuroendocrinology 39:189-191. Medline

Foo KS, Hellysaz A, Broberger C (2014) Expression and colocalization patterns of calbindin-D28K, calretinin and parvalbumin in the rat hypothalamic arcuate nucleus. J Chem Neuroanat 61-62:20-32. CrossRef Medline

Gregorian RS, Golden KA, Bahce A, Goodman C, Kwong WJ, Khan ZM (2002) Antidepressant-induced sexual dysfunction. Ann Pharmacother 36:1577-1589. CrossRef Medline

Igelström KM, Heyward PM (2012) The antidepressant drug fluoxetine inhibits persistent sodium currents and seizure-like events. Epilepsy Res 101:174-181. CrossRef Medline

Jin W, Lu Z (1999) Synthesis of a stable form of tertiapin: a high-affinity inhibitor for inward-rectifier $\mathrm{K}^{+}$channels. Biochemistry 38:1428614293. CrossRef Medline

Jørgensen H, Knigge U, Warberg J (1992) Involvement of 5-HT1, 5-HT2, and $5-\mathrm{HT} 3$ receptors in the mediation of the prolactin response to serotonin and 5-hydroxytryptophan. Neuroendocrinology 55:336-343. Medline

Jørgensen H, Kjaer A, Warberg J, Knigge U (2001) Differential effect of serotonin 5-HT(1A) receptor antagonists on the secretion of corticotropin and prolactin. Neuroendocrinology 73:322-333. CrossRef Medline

Kamberi IA, Mical RS, Porter JC (1971) Effect of anterior pituitary perfusion and intraventricular injection of catecholamines on prolactin release. Endocrinology 88:1012-1020. CrossRef Medline

Kannengiesser MH, Hunt PF, Raynaud JP (1976) Comparative action of fenfluramine on the uptake and release of serotonin and dopamine. Eur J Pharmacol 35:35-43. CrossRef Medline

Karson CN, Newton JE, Livingston R, Jolly JB, Cooper TB, Sprigg J, Komoroski RA (1993) Human brain fluoxetine concentrations. J Neuropsychiatry Clin Neurosci 5:322-329. CrossRef Medline

Kiss J, Halász B (1986) Synaptic connections between serotoninergic axon terminals and tyrosine hydroxylase-immunoreactive neurons in the arcuate nucleus of the rat hypothalamus: a combination of electron microscopic autoradiography and immunocytochemistry. Brain Res 364: 284-294. CrossRef Medline

Léránth C, Sakamoto H, MacLusky NJ, Shanabrough M, Naftolin F (1985) Intrinsic tyrosine hydroxylase (TH) immunoreactive axons synapse with TH immunopositive neurons in the rat arcuate nucleus. Brain Res 331: 371-375. CrossRef Medline

Liang SL, Pan JT (2000) An endogenous serotonergic rhythm acting on $5-\mathrm{HT}(2 \mathrm{~A})$ receptors may be involved in the diurnal changes in tuberoinfundibular dopaminergic neuronal activity and prolactin secretion in female rats. Neuroendocrinology 72:11-19. CrossRef Medline

Loose MD, Ronnekleiv OK, Kelly MJ (1990) Membrane properties and response to opioids of identified dopamine neurons in the guinea pig hypothalamus. J Neurosci 10:3627-3634. Medline

Lu KH, Meites J (1973) Effects of serotonin precursors and melatonin on serum prolactin release in rats. Endocrinology 93:152-155. CrossRef Medline

Lüscher C, Jan LY, Stoffel M, Malenka RC, Nicoll RA (1997) G proteincoupled inwardly rectifying $\mathrm{K}^{+}$channels (GIRKs) mediate postsynaptic but not presynaptic transmitter actions in hippocampal neurons. Neuron 19:687-695. CrossRef Medline

Lyons DJ, Broberger C (2014) TIDAL WAVES: network mechanisms in the neuroendocrine control of prolactin release. Front Neuroendocrinol 35: 420-438. CrossRef Medline

Lyons DJ, Horjales-Araujo E, Broberger C (2010) Synchronized network oscillations in rat tuberoinfundibular dopamine neurons: switch to tonic discharge by thyrotropin-releasing hormone. Neuron 65:217-229. CrossRef Medline

Lyons DJ, Hellysaz A, Broberger C (2012) Prolactin regulates tuberoinfundibular dopamine neuron discharge pattern: novel feedback control mechanisms in the lactotrophic axis. J Neurosci 32:8074-8083. CrossRef Medline

Madhusoodanan S, Parida S, Jimenez C (2010) Hyperprolactinemia associated with psychotropics: a review. Hum Psychopharmacol 25:281-297. CrossRef Medline

Meltzer HY, Young M, Metz J, Fang VS, Schyve PM, Arora RC (1979) Extrapyramidal side effects and increased serum prolactin following fluoxetine, a new antidepressant. J Neural Transm 45:165-175. CrossRef Medline

Montejo AL, Llorca G, Izquierdo JA, Rico-Villademoros F (2001) Incidence of sexual dysfunction associated with antidepressant agents: a prospective multicenter study of 1022 outpatients. Spanish Working Group for the Study of Psychotropic-Related Sexual Dysfunction. J Clin Psychiatry 62 [Suppl 3]:10-21.

Montejo-González AL, Llorca G, Izquierdo JA, Ledesma A, Bousoño M, Calcedo A, Carrasco JL, Ciudad J, Daniel E, De la Gandara J, Derecho J, Franco M, Gomez MJ, Macias JA, Martin T, Perez V, Sanchez JM, Sanchez S, Vicens E (1997) SSRI-induced sexual dysfunction: fluoxetine, paroxetine, sertraline, and fluvoxamine in a prospective, multicenter, and descriptive clinical study of 344 patients. J Sex Marital Ther 23:176-194. CrossRef Medline

Morgan WW, Herbert DC (1978) Elevation of serum prolactin levels after 
the inhibition of serotonin uptake. Endocrinology 103:1016-1022. CrossRef Medline

Mulroney SE, Skudlarek C, Shemer A, Lumpkin MD, Kellar KJ (1994) Tandospirone stimulates prolactin secretion in the rat by an action at serotonin-1A receptors. J Pharmacol Exp Ther 268:862-867. Medline

Olié JP, Elomari F, Spadone C, Lépine JP (2002) Antidepressants consumption in the global population in France. L'Encéphale 28:411-417. Medline

Penington NJ, Kelly JS, Fox AP (1993) Whole-cell recordings of inwardly rectifying $\mathrm{K}^{+}$currents activated by 5-HT1A receptors on dorsal raphe neurones of the adult rat. J Physiol 469:387-405. CrossRef Medline

Petit A, Piednoir D, Germain ML, Trenque T (2003) Drug-induced hyperprolactinemia: a case-non-case study from the national pharmacovigilance database. Thérapie 58:159-163. Medline

Pilotte NS, Porter JC (1981) Dopamine in hypophysial portal plasma and prolactin in systemic plasma of rats treated with 5-hydroxytryptamine. Endocrinology 108:2137-2141. CrossRef Medline

Quattrone A, Schettini G, Di Renzo GF, Preziosi P (1979) Pharmacological evidence of an interaction between serotonergic and dopaminergic neurons in the control of prolactin secretion in male rats. Arch Int Pharmacodyn Ther 238:42-49. Medline

Saenz del Burgo L, Cortes R, Mengod G, Zarate J, Echevarria E, Salles J (2008) Distribution and neurochemical characterization of neurons expressing GIRK channels in the rat brain. J Comp Neurol 510:581-606. CrossRef Medline

Safarinejad MR (2008) Evaluation of endocrine profile and hypothalamicpituitary-testis axis in selective serotonin reuptake inhibitor-induced male sexual dysfunction. J Clin Psychopharmacol 28:418-423. CrossRef Medline

Schlechte J, Sherman B, Halmi N, VanGilder J, Chapler F, Dolan K, Granner D, Duello T, Harris C (1980) Prolactin-secreting pituitary tumors in amenorrheic women: a comprehensive study. Endocr Rev 1:295-308. CrossRef Medline

Siever LJ, Murphy DL, Slater S, de la Vega E, Lipper S (1984) Plasma prolactin changes following fenfluramine in depressed patients compared to controls: an evaluation of central serotonergic responsivity in depression. Life Sci 34:1029-1039. CrossRef Medline

Steele EC Jr, Chen X, MacLeish PR (2005) Fluoxetine inhibits calciumactivated currents of salamander rod photoreceptor somata and presynaptic terminals via modulation of intracellular calcium dynamics. Mol Vis 11:1200-1210. Medline

Tytgat J, Maertens C, Daenens P (1997) Effect of fluoxetine on a neuronal, voltage-dependent potassium channel (Kv1.1). Br J Pharmacol 122: 1417-1424. CrossRef Medline

Urban RJ, Veldhuis JD (1991) A selective serotonin reuptake inhibitor, fluoxetine hydrochloride, modulates the pulsatile release of prolactin in postmenopausal women. Am J Obstet Gynecol 164:147-152. CrossRef Medline

van Geffen EC, van der Wal SW, van Hulten R, de Groot MC, Egberts AC, Heerdink ER (2007) Evaluation of patients' experiences with antidepressants reported by means of a medicine reporting system. Eur J Clin Pharmacol 63:1193-1199. CrossRef Medline

Vos T, Flaxman AD, Naghavi M, Lozano R, Michaud C, Ezzati M, Shibuya K, Salomon JA, Abdalla S, Aboyans V, Abraham J, Ackerman I, Aggarwal R, Ahn SY, Ali MK, Alvarado M, Anderson HR, Anderson LM, Andrews KG, Atkinson C, et al. (2012) Years lived with disability (YLDs) for 1160 sequelae of 289 diseases and injuries 1990-2010: a systematic analysis for the Global Burden of Disease Study 2010. Lancet 380:2163-2196. CrossRef Medline

Wong DT, Bymaster FP, Engleman EA (1995) Prozac (fluoxetine, Lilly 110140), the first selective serotonin uptake inhibitor and an antidepressant drug: twenty years since its first publication. Life Sci 57:411-441. CrossRef Medline

World Health Organisation (2008) The global burden of disease: 2004 Geneva: World Health Organisation.

Zhang X, van den Pol AN (2015) Dopamine/tyrosine hydroxylase neurons of the hypothalamic arcuate nucleus release GABA, communicate with dopaminergic and other arcuate neurons, and respond to dynorphin, Met-enkephalin, and oxytocin. J Neurosci 35:14966-14982. CrossRef Medline 